SINAI Journal of Applied Sciences 10 (2) 2021 187-204

\begin{tabular}{lll} 
Available online at www.sinjas.journals.ekb.eg & $\overline{\text { SRU-EGYPT }}$ \\
\hline & SCREENED BY SINAI Journal of Applied Sciences & Print ISSN 2314-6079
\end{tabular}

\title{
AN ECONOMIC STUDY OF WATER RESOURCES IN NORTH SINAI GOVERNORATE
}

\author{
Shmoaa A. Mohamed ${ }^{1 *}$ and M.A. EIShahed ${ }^{2}$ \\ 1. Dept. Econ. and Rural Develop., Fac. Environ. Agric. Sci., Arish Univ., Egypt. \\ 2. Dept. Econ., Fac. Fisheries, Suez Univ., Egypt.
}

\begin{tabular}{l} 
ARTICLE INFO \\
\hline Article history: \\
Received: $19 / 09 / 2021$ \\
Revised: $20 / 10 / 2021$ \\
Accepted: 04/11/2021 \\
Available online: 04/11/2021 \\
\hline Keywords: \\
Water sources, \\
surface wells, \\
statistical measurement, \\
total elasticity
\end{tabular}

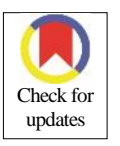

\begin{abstract}
The research aims in general to study the efficiency of using surface wells in North Sinai farms, and the most important water factors affecting the production of the most important plant crops under the drip irrigation system. The research was mainly based on primary data through a field questionnaire for a stratified random sample of surface wells consisting of 112 wells based on the relative importance of surface wells. A stratified random sample was selected from 95 farms producing vegetable and fruit crops with a drip irrigation system during 2020 production season. He indicated that the number of wells in the North Sinai governorate reached about 2,198 wells, of which private wells contribute about 93.2\% during 2019. As for the geographical distribution of the surface wells in the private sector, the results indicated that: Al-Arish center occupies the first place among the governorate, with relative importance It is about $45.3 \%$, while Al-Hasana Center occupies the last place by about $4.6 \%$ during 2019 . With regard to the results of the statistical measurement of the effect of water factors of the quantity of production of plant farms under the drip irrigation system, the results showed that the most influential water factors are the amount of irrigation water per thousand cubic meters in the season, the number of irrigation hours per day, the number of irrigation times per year and finally the salinity of the irrigation water per thousand parts per million.
\end{abstract}

$$
\begin{aligned}
& \text { ونظر اً لأهمية المياه للتنمية الاجتماعية والاقتصادية تقوم }
\end{aligned}
$$

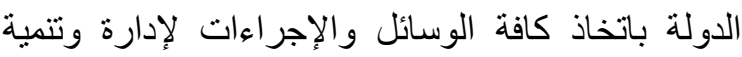

$$
\begin{aligned}
& \text { الموارد والاستخدامات المائية بطريقة متكاملة وعادلة }
\end{aligned}
$$

(Allen and Sweeney, 1985)

$$
\begin{aligned}
& \text { وقد أدى التزايد السكاني المضطرد إلى زيادة الطلب }
\end{aligned}
$$

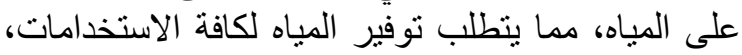

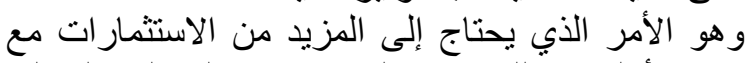

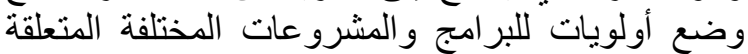

$$
\begin{aligned}
& \text { بالمياه (غادة الدمراوي، 2013). } \\
& \text { هذا وقد أصبحت قضية المياه من أهم القضايا التي } \\
& \text { تواجه الكثير من المجتمعات و وعلى الأخص في مجال إنتاج } \\
& \text { الغذاء. لذا كان لمصر وهن الكى الأجدر من غير ها من العديد }
\end{aligned}
$$

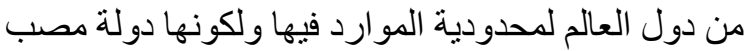

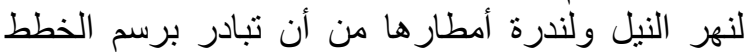

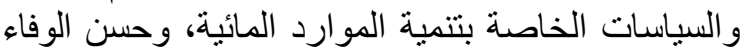

$$
\begin{aligned}
& \text { بمتطلبات القطاعات المستخدمة للمياه (السيد، 2011)، }
\end{aligned}
$$

\footnotetext{
* Corresponding author: E-mail address: shmoaaawad@gmail.com https://doi.org/10.21608/sinjas.2021.96940.1051

(C) 2021 SINAI Journal of Applied Sciences. Published by Fac. Environ. Agric. Sci., Arish Univ. All rights reserved.
} 
4- دراسة الأهمية النسبية للنود هيكل التكاليف لري التئي الزروع النباتية باستخدام الآبار السطحية داخل عينة الدر اسة.

\section{مصادر البيانات والطريقة البحثية}

اعتمد البحث في تحقيق أهدافه على أسلوب التحليل

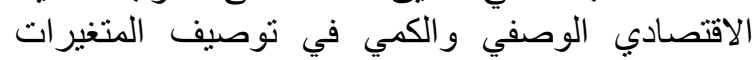

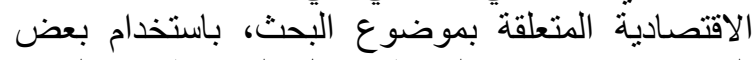

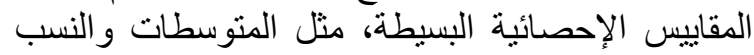

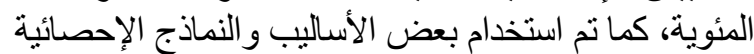

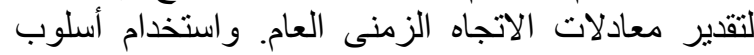

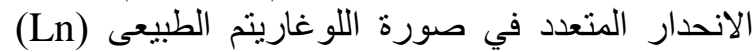

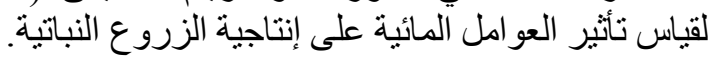

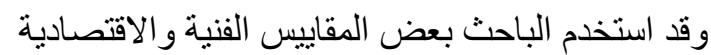
في توصيف الآبار السطحية بعينة البحث بهدف العثة الحكم على كفاءة استخدامها.

و واستند الباحث إلى البيانات الثانوية المنشورة وغير التئير

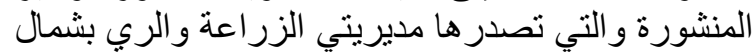

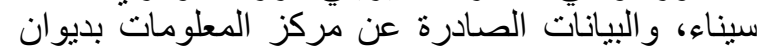

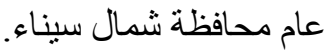

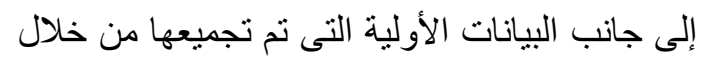

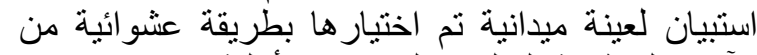

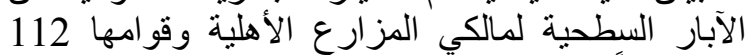

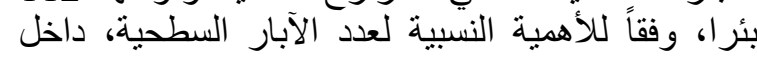

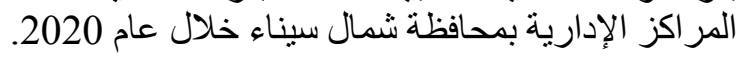

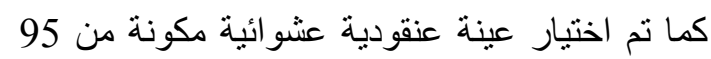

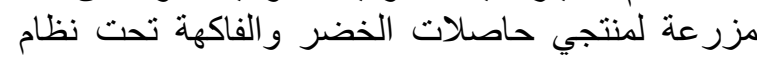
الري بالتنقيط خلال موسم إنتاج عام 2020.

\section{النتائج ومناقشتها}

مصادر المياه المتاحة للرى في محافظة شمال سيناء

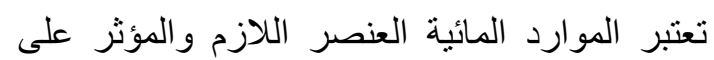

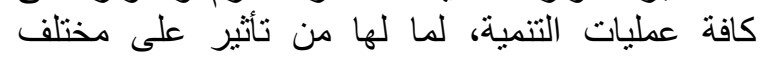

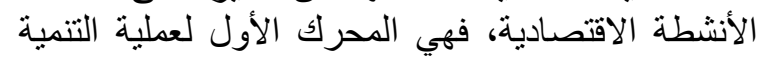

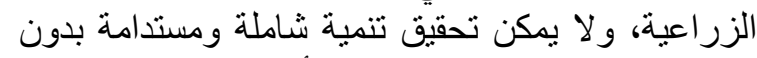
توفير كميات كافية من المباه تحقق أهداف التنمية تلنية الزراعية

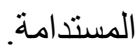

و وعلى الرغم من المساحات الثاسعة من الأراضي

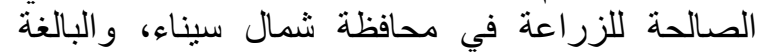

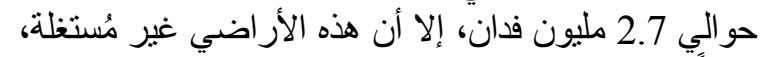

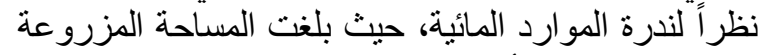

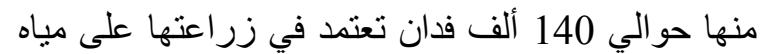
الأمطار و ألسيول و المياه الجوفية.

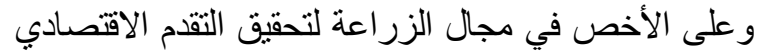

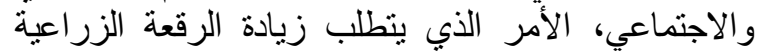

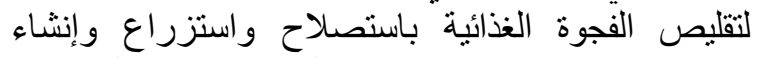

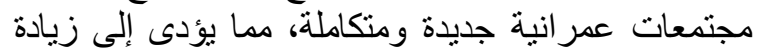

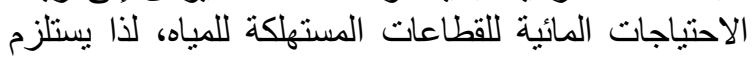

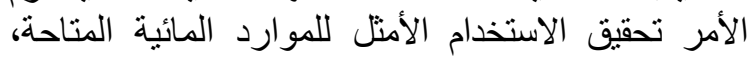

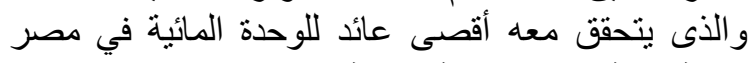
بصفة عامة وسيناء بصفة خاصة ألمان.

مشكلة البحث

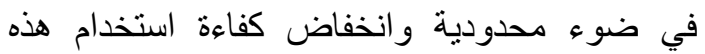

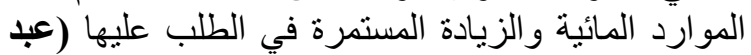

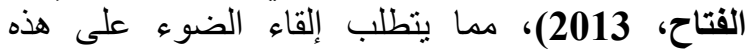

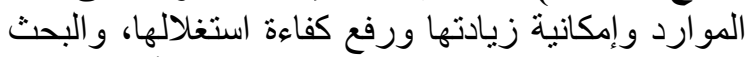

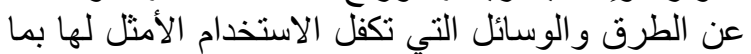

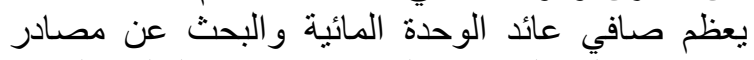

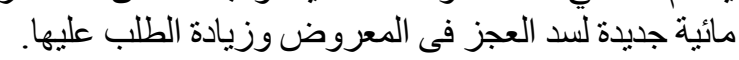

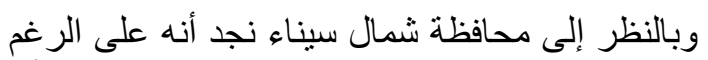

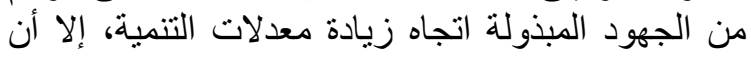

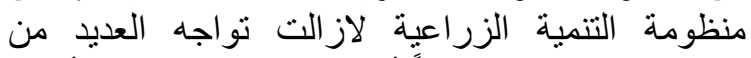

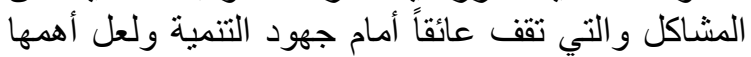

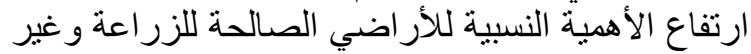

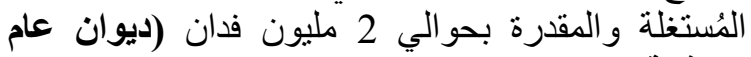

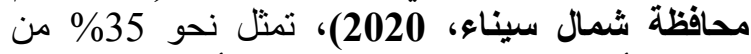

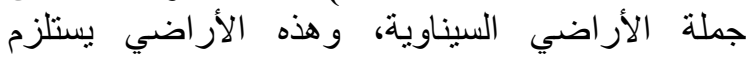

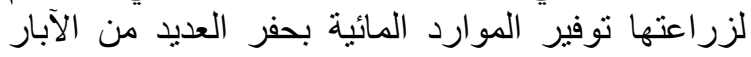

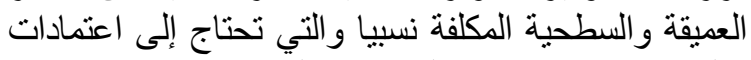

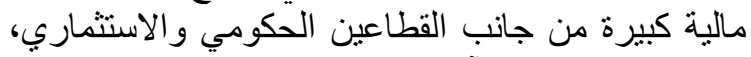

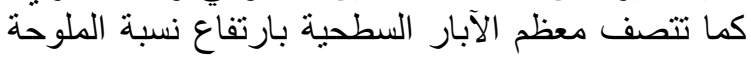

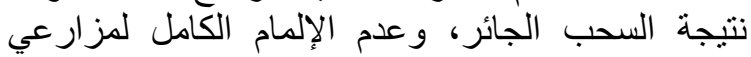
شمال سيناء بالاحتباجات المائية المنلى للزروع الإلى النباتية. أهداف البحث

يستهدف البحث بصفة عامة دراسة كفاءة استخدام

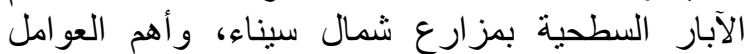

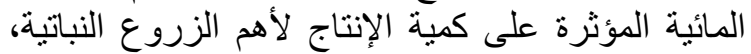

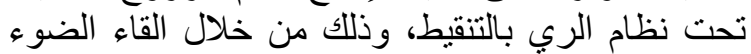
على الأهداف الفر عية النالية:

1- دراسة الوضع الراهن للموارد الهية المائية المتاحة في

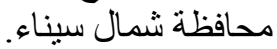

2- استعر اض الوضع الر اهن للآبار السطحية داخل عينة البحث في محافظة شمال سيناء.

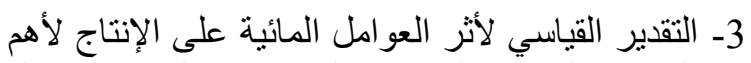

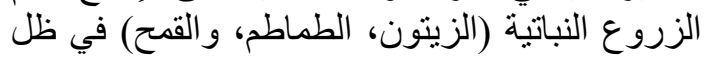

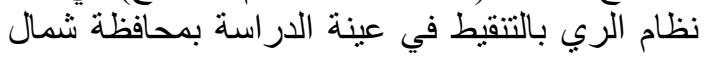


، و التوزيع الجغر افي لهذه الآبار داخل مختلف المر اكز

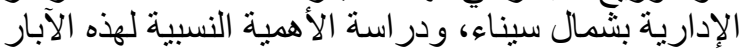

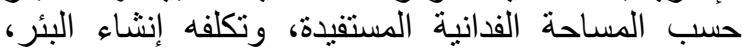

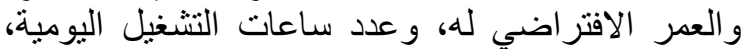
والتصرف المائي لمياه الآبار في الساعةد، وكمبة المئية المياه

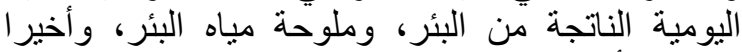
دراسة الأهمية النسبية لبنود هيكل تكاليف الرئ الري باستخدام الآبار السطحية داخل عينه البحث بشمال سيناء خلال عام

\section{عدد الآبار الأهلية}

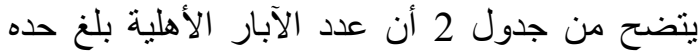

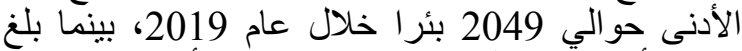
حده الأقصى حوالي 4319 بئر فى الأعوام من عام 2014 المي

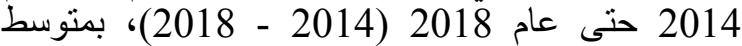

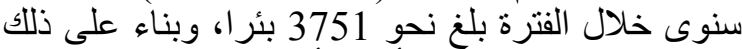
يمكن إستتناج تز ايد عدد الأبار الأهلية بمرور الزمن.

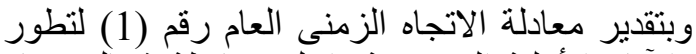
عدد الآبار الأهلية المرخصة داخل الآل محافظة شمال سيناء خلال الفترة (2008-2019) تبين من النيار النتائج أن معدل النزايد السنوى غير المعنوى إحصائيا.

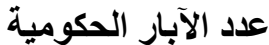

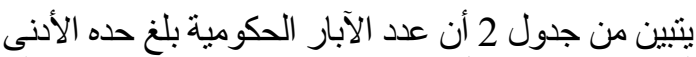

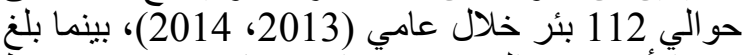

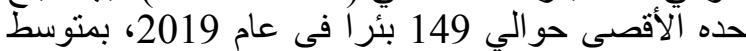

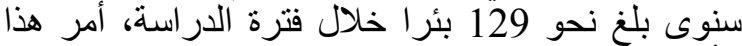
شأنه ربما يعكس زيادة عدد الابار الحكومية بمرور الزمن.

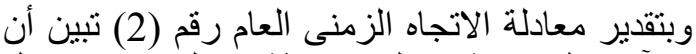

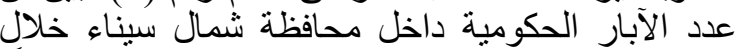
الفترة (2008-2019)، نتاقص بمعدل غير معنوي إحصائياً.

\section{إجمالى عدد الآبار فى محافظة شمال سيناء}

يتبين من جدول 2 أن أجمالي عدد الآبار داخل محافظة

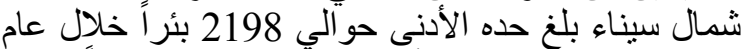

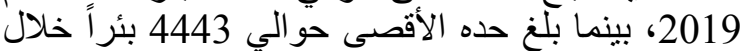
الفترة (2015 - 2018)، بمنوسط سنوى بلغ نحو 3880 بئر ا خلال فترة الدر اسة.

وبتقدير معادلة الاتجاه الزمنى العام رقم (3) تبين أن أنماء

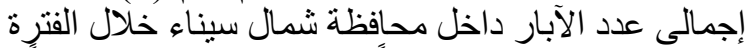

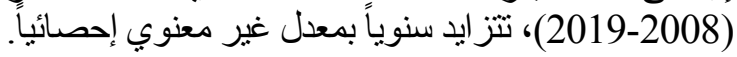

\section{تطور كمية المياه المنتجة من الآبار سنوياً:}

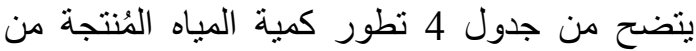

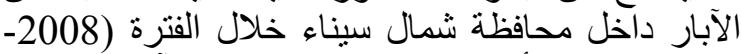

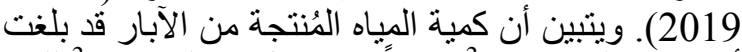

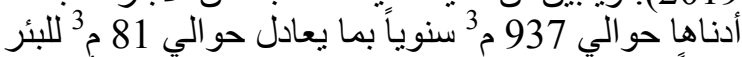

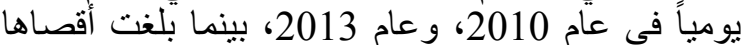

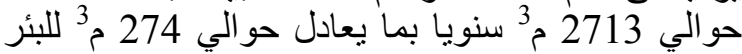

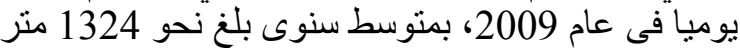
مكعب سنويا خلال فترة الدر استة.
وتتحصر مصادر المياه في محافظة شمال سيناء في مصدرين رئيسين فقط هما، مبآه الأمطار و السيول، و الميآه الجوفية و الخنادق و المو اصئي مياه الأمطار و السيول

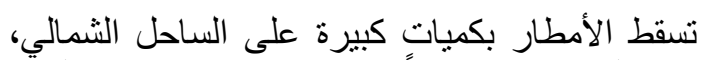

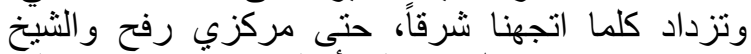

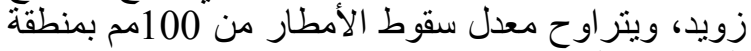

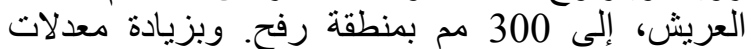
سقوط الأمطار تتكون السيول في روالفي الف وادي العريش

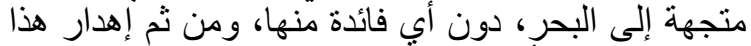

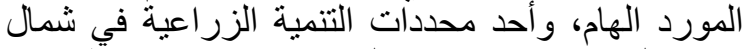

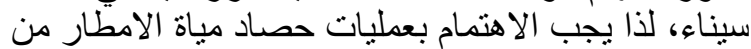

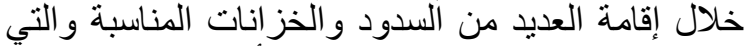

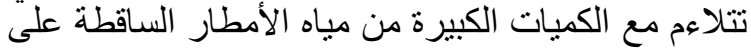
تللك المناطق. وبلغ المتوسط السنوى للطاقة الاستيعابية

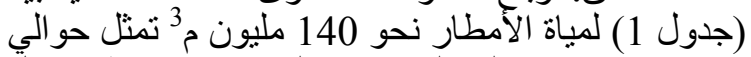
51.18\% من إجمالي المتاح من المياه في محافظة شمال

$$
\text { سيناء. }
$$

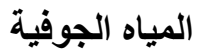

تعتبر المياه الجوفية أحد المصادر الهامة من مصاديادر

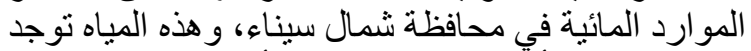

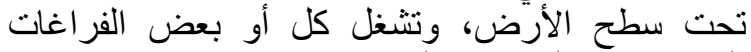

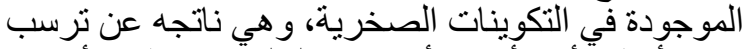

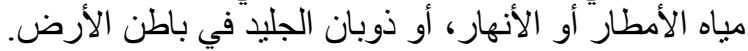

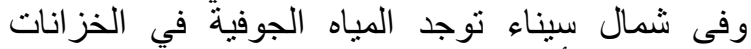

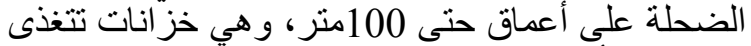

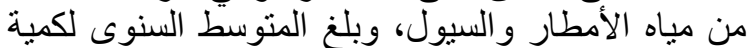

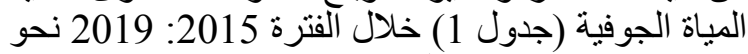

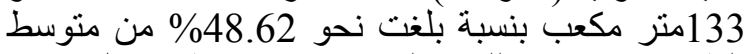
الطاقة الاستيعابية للمياة المتاحة فى محافظة شمال سيناء

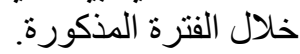

$$
\text { الخنادق والمواصي }
$$

هي عبارة عن خنادق تحفر بمناطق الكثبان الرملية

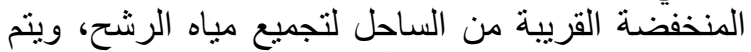

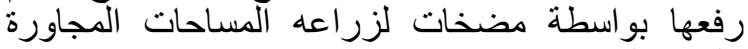

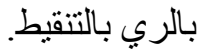

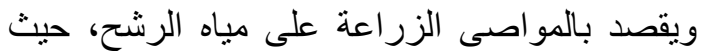

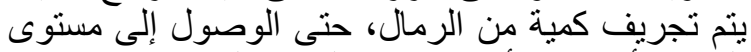

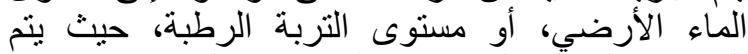
الزر اعة على هذه الرطوبة، وبلغ متوسط الطاقة الاستيعابية الطية

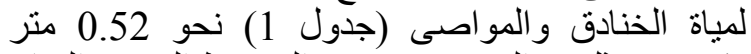

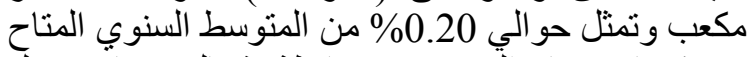
من كميات مياة الرىى فى محافظة شمال سيناء خلاءل الفترة 2015: 2019.

\section{عدد الأبار الأهلية والحكومية بمحافظه شمال سيناء}

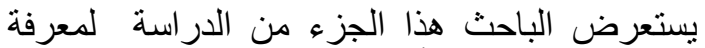

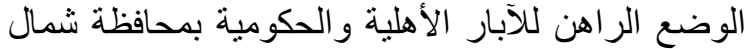
سيناء، من حيث عددها، و كمية المياه المنتجة سنويا منها 
جلول 1. كمية مياه الرى المتاحة من المصادر الرئيسية في محافظة شمال سيناء خلال الفترة (2015- 2019)

\begin{tabular}{|c|c|c|}
\hline الأهمية النسبية & الطاقة الاستيعابية (كمية المياه المنتجة) & 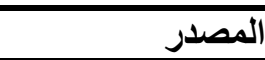 \\
\hline$\% 51.18$ & 140 م³/ سنة & الأمطار \\
\hline$\% 48.62$ & 133 مُ3/ سنة & المياه الجوفية \\
\hline$\% 0.20$ & ( 0.52 م3 / سنة & الخنادق و المواصي \\
\hline$\% 100$ & 273.52 & 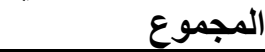 \\
\hline
\end{tabular}
.2020

جدول 2. عدد الآبار الأهلية (المرخصة) والحكومية داخل محافظة شمال سيناء خلال الفترة (2008- 2019)

\begin{tabular}{|c|c|c|c|}
\hline جمله & آبار حكومية & آبار أهلية & السنة \\
\hline 3304 & 142 & 3162 & 2008 \\
\hline 3304 & 142 & 3162 & 2009 \\
\hline 3590 & 138 & 3452 & 2010 \\
\hline 3590 & 138 & 3452 & 2011 \\
\hline 4126 & 116 & 4010 & 2012 \\
\hline 4242 & 112 & 4130 & 2013 \\
\hline 4431 & 112 & 4319 & 2014 \\
\hline 4443 & 124 & 4319 & 2015 \\
\hline 4443 & 124 & 4319 & 2016 \\
\hline 4443 & 124 & 4319 & 2017 \\
\hline 4443 & 124 & 4319 & 2018 \\
\hline 2198 & 149 & 2049 & 2019 \\
\hline 3880 & 129 & 3751 & المتوسط \\
\hline 100 & 3.3 & 96.7 & $(\%)$ \\
\hline
\end{tabular}

جدول 3. الاتجاه الزمني العام لعدد الآبار الأهلية والحكومية وكمية المياة المنتجة داخل محافظة شمال سيناء خلاءل الرية الفترة

(2019-2008)

\begin{tabular}{|c|c|c|c|c|c|}
\hline $\mathbf{F}$ & $\mathbf{R}^{2}$ & التغير السنوي معدل & معادلات الاتجاه الزمني العام & المتغيرات & رقمادثة \\
\hline 0.30 & 0.02 & 0.90 & $\begin{array}{l}\hat{\mathbf{Y}}=3530.77+33.88 \mathbf{T}_{\mathbf{i}} \\
(7.78)(0.55)\end{array}$ & عدد الآبار الأهلية & 1 \\
\hline 0.55 & 0.05 & 0.60 & $\begin{array}{l}\hat{\mathbf{Y}}=133.95-0.80 \mathbf{T}_{\mathbf{i}} \\
(16.9)(-0.74)\end{array}$ & عدد الآبار الحكومية & 2 \\
\hline 0.29 & 0.02 & 0.85 & $\begin{array}{l}\hat{\mathbf{Y}}=3664.7+33.08 \mathbf{T}_{\mathbf{i}} \\
(8.20)(0.54)\end{array}$ & إجمالى عدد الابار & 3 \\
\hline 2.68 & 0.21 & 6.3 & $\begin{array}{l}\hat{\mathbf{Y}}=1870.4-83.9 \mathbf{T}_{\mathbf{i}} \\
(4.95)(-1.63)\end{array}$ & كمية المياة المنتجة من الابار & 4 \\
\hline
\end{tabular}

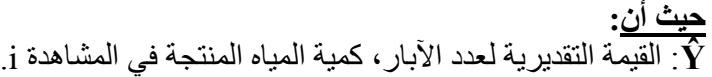

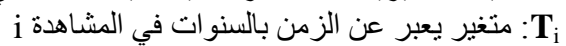

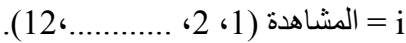
المصدر: جمعت وحسبت من بيانات جدولى (1، (4، (4). 
جدول 4. كمية المياه المنتجة من الآبار داخل محافظة شمال سيناء خلال الفترة (2008، 2019)

\begin{tabular}{|c|c|c|}
\hline م. نصيب البئر (م³/ يوم) & كمية المياه (مُ3/ سنـه) & السنة \\
\hline 135 & 1287 & 2008 \\
\hline 274 & 2713 & 2009 \\
\hline 81 & 937 & 2010 \\
\hline 131 & 1291 & 2011 \\
\hline 240 & 2705 & 2012 \\
\hline 81 & 937 & 2013 \\
\hline 81 & 984 & 2014 \\
\hline 82 & 1000 & 2015 \\
\hline 82 & 997 & 2016 \\
\hline 80 & 973 & 2017 \\
\hline 80 & 973 & 2018 \\
\hline 108 & 1099 & 2019 \\
\hline 121.3 & 1324.7 & المتوسط \\
\hline
\end{tabular}

المرتبة الثالثة، بأهمية نسبية نحو 13.6\%ة ؤبة ومركزي

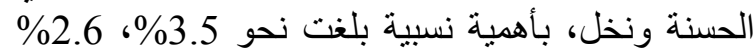

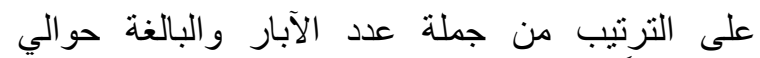
2049بئراً خلال عام 2019. لذا فقد نم اختبار عينة عشوائية طبقية من الآبار السطحية قوام امها 112 بئراً،

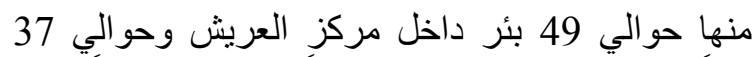
بئر اً داخل مركز بئر العبد وأخيراً حو الي 26 بئر اً داخل

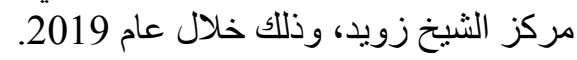

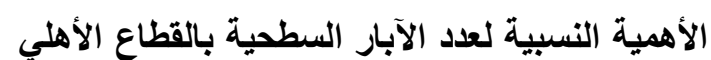

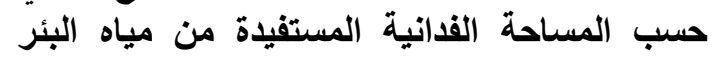
بعينة البحث في محافظة شمال سيناء خلاء خلال عام البنام 2020

يوضح جدول 6 الأهمية النسبية لعدد الآبار السطحية

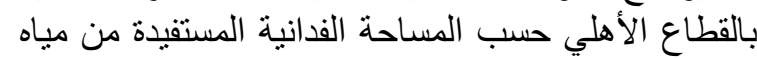
البئر بعينة البحث، ومنه يتبين وجود حوالي الإلي 7 آبار ، تمثل من التياه نحو 6.3\% من جملة عدد الآبار تقل مساحتها المستفيدة

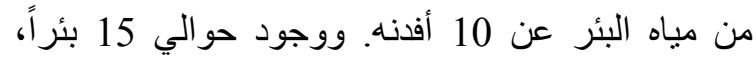

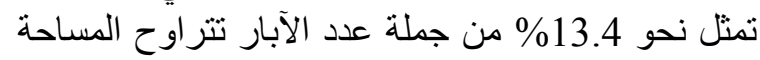

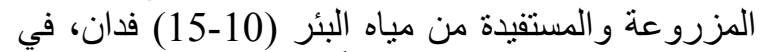

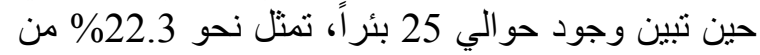

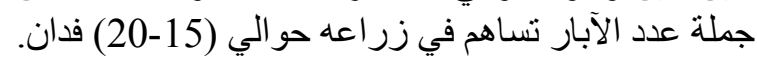

ويتضح من المعادلة رقم (4) بجدول 3 أن كمية المياة

المنتجة من الابار تتناقص بمقدار غير معنوي إحصائياً.

التوزيع الجغرافي لعدد الآبار الأهلية والحكومية لإبية

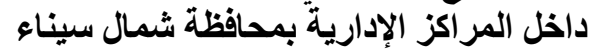

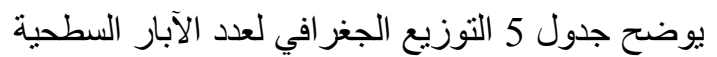

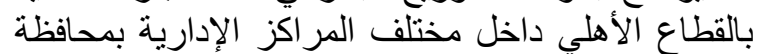

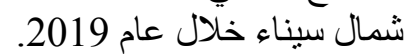

يتبين من الجدول: أن مركز العريش يحتل المرتبة

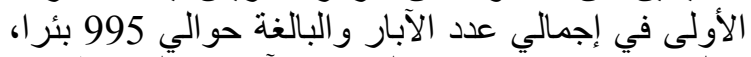

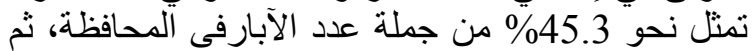

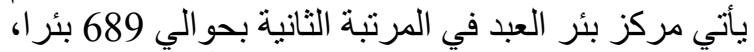

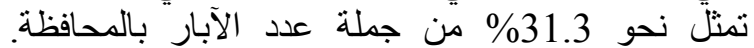
ويحتل مركز الثيخ زويد المرتبة الثالثة بحوالي 279 بئر ا، تمثل نحو 12.7\% من جملة عدد الآبار.

$$
\text { اختيار عينة البحث }
$$

في ضوء الأهمية النسبية لعدد الآبار داخل المر اكز

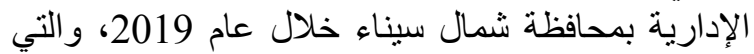

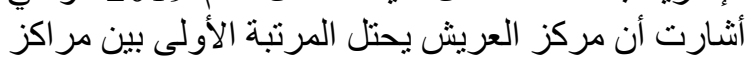

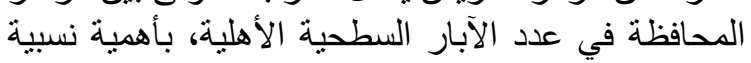

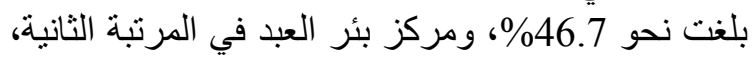

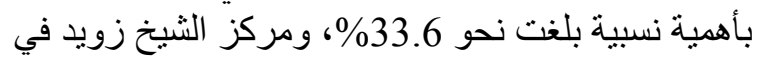


جلول 5. توزيع الآبار الأهلية والحكومية وفقا للمركز الإدارى بمحافظة شمال سيناء خلال عام 2019

\begin{tabular}{|c|c|c|c|c|c|c|}
\hline \multicolumn{6}{|c|}{ عدد الآبار } & \multirow[t]{2}{*}{ المركز } \\
\hline$(\%)$ & جملة & $(\%)$ & حكومي & $(\%)$ & أهلي & \\
\hline- & - & - & - & - & - & رفح \\
\hline 12.7 & 279 & 0.7 & 1 & 13.6 & 278 & الشيخ زويد \\
\hline 45.3 & 995 & 25.5 & 38 & 46.7 & 957 & العريش \\
\hline 31.3 & 689 & - & - & 33.6 & 689 & بئر العبد \\
\hline 4.6 & 102 & 20.8 & 31 & 3.5 & 71 & الحسنة \\
\hline 6.1 & 133 & 53 & 79 & 2.6 & 54 & نخل \\
\hline 100 & 2198 & 100 & 149 & 100 & 2049 & جملة \\
\hline 100 & 100 & 100 & 7.6 & 100 & 93.2 & $\%$ \\
\hline
\end{tabular}

جدول 6. الأهمية النسبية لعدد الآبار السطحية بالقطاع الأهلي حسب المساحة الفدانية المستفيدة من مياه البئر بعينة البحث في محافظة شمال سيناء خلال عام 2020

\begin{tabular}{|c|c|c|}
\hline$(\%)$ & عدد الآبار & فئة المساحة الفدانية (فدان) \\
\hline 6.3 & 7 & $(\mathbf{1 0}-\mathbf{0})$ \\
\hline 13.4 & 15 & $(15-10)$ \\
\hline 22.3 & 25 & $(20-15)$ \\
\hline 33 & 37 & $(25-20)$ \\
\hline 25 & 28 & 25 فدان فأكثر \\
\hline 100 & 112 & عدد الآبار \\
\hline & & متوسط المساحة المستفيدة من ري \\
\hline
\end{tabular}

تمثل نحو 64.3\% من جملة عدد الآبار تصل تكلفه إنشائها إلى حو الي 65 ألف جنيه فأكثر.

هذا وقد بلغ المتوسط العام لتكلفة إنثاء البئر حوالي 72.8 ألف جنيه خلال عام 2020.

الأهمية النسبية لعدد الآبار السطية بالقطاع الأهلي

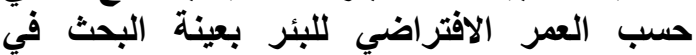
محافظة شمال سيناء خلال عام 2020

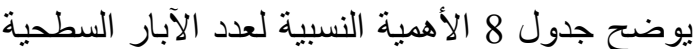

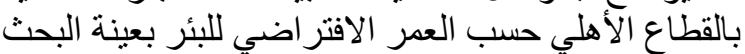

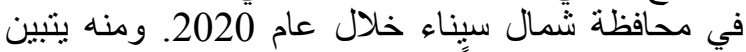

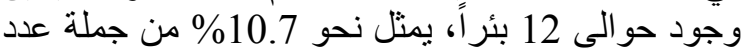

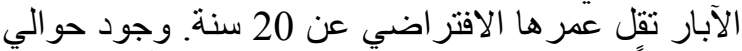

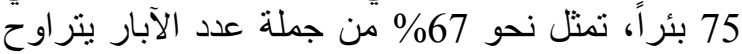
عر ها الافتر اضي بين (20 -25) سنة.

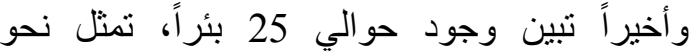

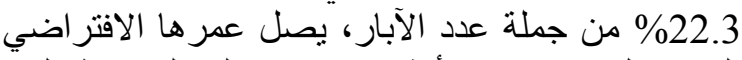

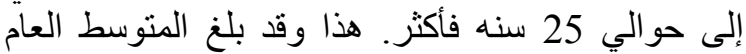
لعمر البئر الافتر اضي حو الي 24.6 سنه خلال عام 2020.
كما تبين وجود 37 بئر ا، تمثل نحو 33\% من جمار وملة

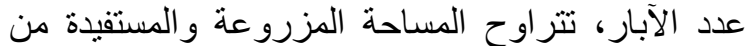
مياه البئر حو الي (20- 25) فدار الن.

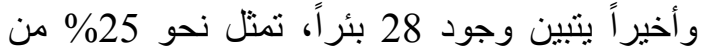
جملة عدد الآبار، تساهم في زراعن واعه حوالي 25 فدان

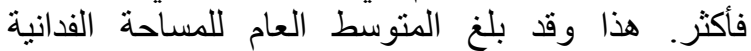
المزروعة والمستفيدة من مياه البئر حوالي 20.4 فلدان خلال عام

الأهمية النسبية لعدد الآبار السطية حسب تكائة إنشاء البئر بعينة البحث في محافظة شالار البمال سيناء خلال عام اليز 2020

يوضح جدول 7 الأهمية النسبية لعدد الآبار السطحية حسب تكلفه إنشاء البئر بعينة البحث في محافظة شمال

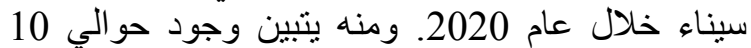
آبار، تمثل نحو 8.9\% من جملة عدد الآبار تقل تكلفتها

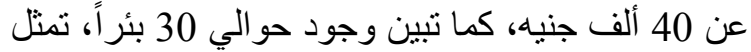
نحو 26.8\% من جملة عدد الآبار تتراوح تكلفه أنشائها

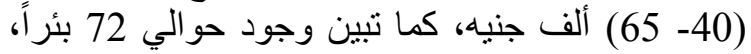


جدول 7. الأهمية النسبية لعدد الآبار السطحية بالقطاع الأهلي حسب تكلفه إنثاء البئر بعينة البحث في محافظة شمال

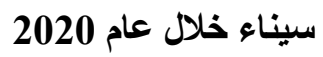

\begin{tabular}{|c|c|c|}
\hline$(\%)$ & عدد الآبار & تكلفة الإنشاء (ألف جنية) \\
\hline 8.9 & 10 & $(40-0)$ \\
\hline 26.8 & 30 & $(65-40)$ \\
\hline 64.3 & 72 & 65 فأكثر \\
\hline 100 & 112 & عدافد الآبار \\
\hline
\end{tabular}

جدول 8. الأهمية النسبية لعدد الآبار السطية بالقطاع الأهلي حسب العمر الافتراض للبئر بعينة البحث في محافظة شمال سيناء خلال عام لالابار العبط 2020

\begin{tabular}{|c|c|c|}
\hline$(\%)$ & عدد الآبار & فئنة العمر الافترز اضي (سنة) \\
\hline 10.7 & 12 & أقَّل من 20 \\
\hline 67 & 75 & $(25-20)$ \\
\hline 22.3 & 25 & 25 فأكثر \\
\hline 100 & 112 & عدد الآبار \\
\hline & & م. العمر الافتراضي للبئر \\
\hline
\end{tabular}

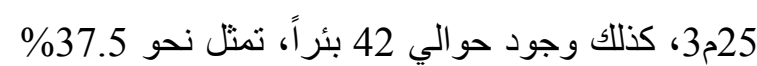

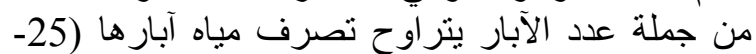

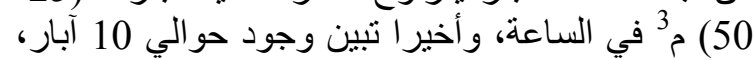

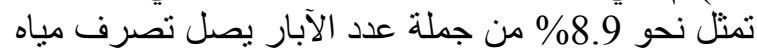

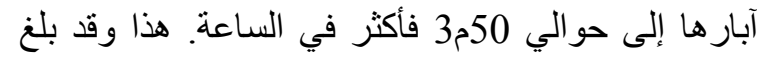

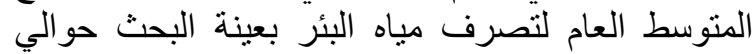

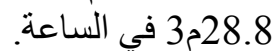

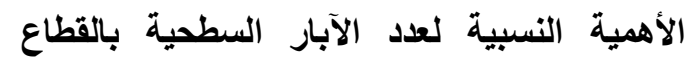
الأهلي حسب كمية المياه اليومية الناتجة من البئر الئر بعينة البحث في محافظة شمال سيناء خلال الئل عام البئ 2020

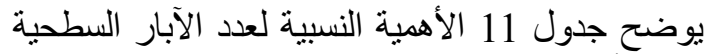

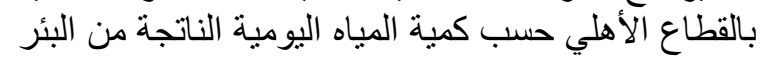

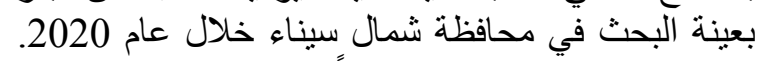

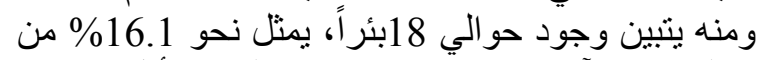

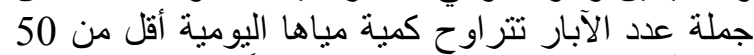

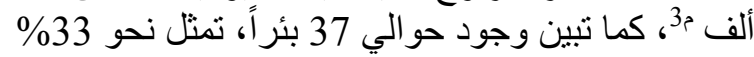

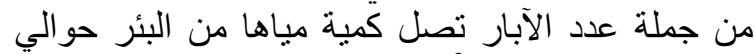

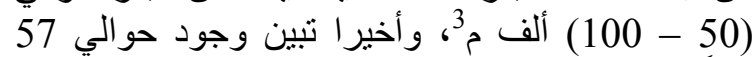
بئر أ، تمثل نحو 50.9\% من جملة عدد الآبار تصل كمية ولية

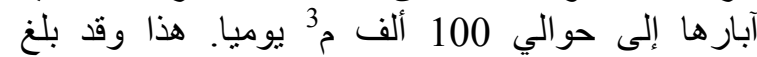
المنوسط العام لكمية مياه البئر اليومية داخل عبنة البئ البحث

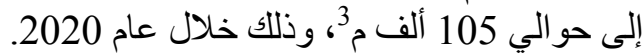

الأهمية النسبية لعدد الآبار السطحية بالقطاع الأهلي

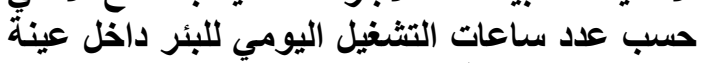
البحث في محافظة شمال سيناء خلال عام للئل 2020 يوضح جدول 9 الأهمية النسبية لعدد الآبار السطحية

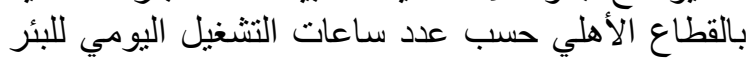
داخل عينة البحث في محافظة شمال سيناء خلال عام لام لائر

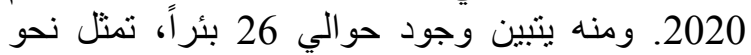
23.2\% من جملة عدد الآبار، تقل عدد ساعات تشئ تشغيلها

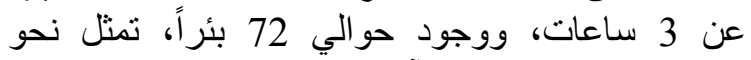

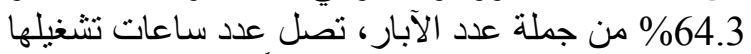

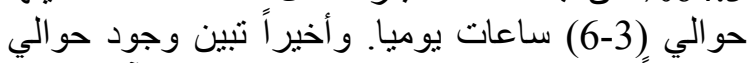

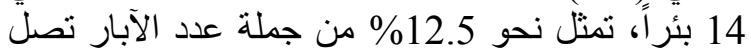

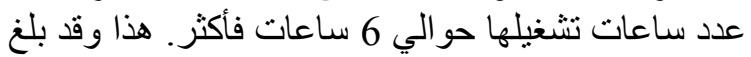
المنوسط العام لعدد ساعات التشغيل اليومي للبئر حوالي 3 3.8 ساعة.

الأهمية النسبية لعدد الآبار السطحية بالقطاع الأهلي حسب تصرف مياه البئر بعينة البحثث في محافظة شمال سيناء خلال عام 2020

يوضح جدول 10 الألهمية النسبية لعدد الآبار السطحية

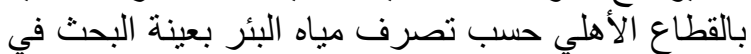

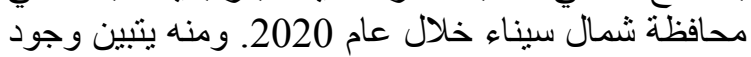

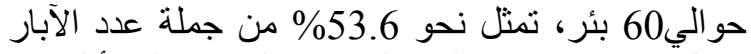
يصل تصرف مياه البئر لها في الساعة إلى أقل من الابن 
جدول 9. الأهية النسبية لعدد الآبار السطية بالقطاع الأهلي حسب عدد ساعات التثغيل اليومي بعينة البحث في محافظة شمال سيناء خلال عام 2020

\begin{tabular}{|c|c|c|}
\hline$(\%)$ & عدد الآبار & فئَات عدد سـاعات التشغيل اليومي (ساعة) \\
\hline 23.2 & 26 & $\overline{(3-0)}$ \\
\hline 64.3 & 72 & $(6-3)$ \\
\hline 12.5 & 14 & 6 فأكثر \\
\hline 100 & 112 & عدد الآبار \\
\hline \multicolumn{2}{|c|}{3.8 ساعة } & م. عدد ساعات التشغيل اليومية \\
\hline
\end{tabular}

جدول 10. الأهمية النسبية لعدد الآبار السطحية بالقطاع الأهلي حسب التصرف المائي لمياه البئر في الساعة بعينة

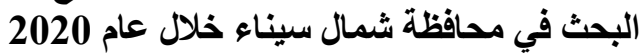

\begin{tabular}{|c|c|c|}
\hline$(\%)$ & عدد الآبار & فُئات تصرف مياه البئر في الساعة (مُ3) \\
\hline 53.6 & 60 & $(25-0)$ \\
\hline 37.5 & 42 & $(50-25)$ \\
\hline 8.9 & 10 & 50 فأكثر \\
\hline 100 & 112 & عدد الآبار \\
\hline \multicolumn{2}{|c|}{ 3 28.8} & م. تصرف مياه البئر في الساعة \\
\hline
\end{tabular}

جدول 11. الأهمية النسبية لعدد الآبار السطحية بالقطاع الأهلي حسب كمية المياه اليومية الناتجة من البئر بعينة البحث في محافظة شمال سيناء خلال عام 2020

\begin{tabular}{|c|c|c|}
\hline$(\%)$ & عدد الآبار & فئات كمية المياه اليومية الناتجة من البئر (ألف م3) \\
\hline 16.1 & 18 & أَقْل من 50 \\
\hline 33 & 37 & $(100-50)$ \\
\hline 50.9 & 57 & 100 \\
\hline 100 & 112 & عدد الآبار \\
\hline \multicolumn{2}{|c|}{105 ألف م33 } & م. تصرف مياه البئر في اليوم \\
\hline
\end{tabular}


للبئر، بما يوازى حو الي 268.5 جنيهاً للفدان، تمثل نحو

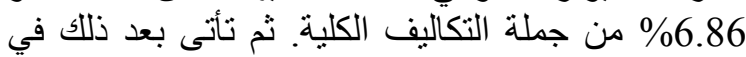
الترتيب بنود الصبانة، قطع الغيار والمهمات، بأهمية نسبية بلغت نحو 3.67\%، 2.71\% من جملة التكاليف

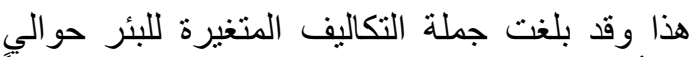

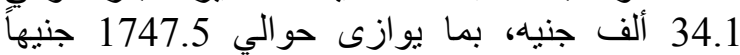
للفدان، تمثل نحو 45.2\% من جملة التكاليف الكلية.

\section{هيكل التكاليف داخل مركز بئر العبد}

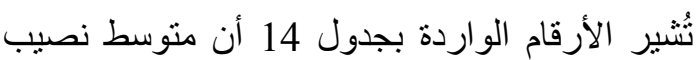

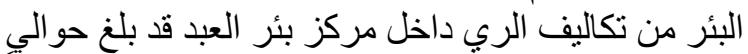

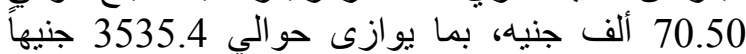
للفدان، ساهمت فيها التكاليف الثابتة بحو التي 40.5 ألف جنيه لللئر ، بما يوازى حوالي 2038.2 جنيهاً للفدان، تمثل نحو 57.5 من جملة التكاليف. وتحتل تكاليف الإهلاك الإك لشبكة الري المرتبة الأولى بين بنود التكاليف ونليف الثابتة

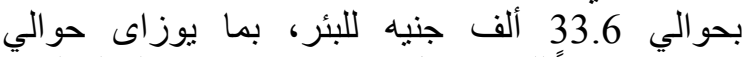
1682.3 جنيهاً للفدان، تمثل نحو 47.7 \%

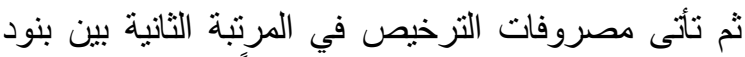

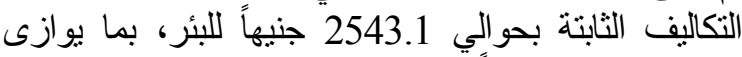

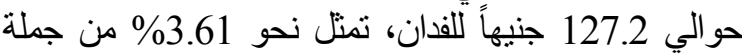

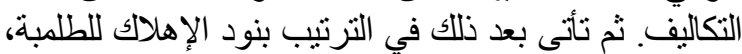

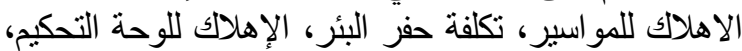

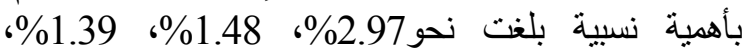
0.37 من جملة التكاليف الكلية.

وتحتل تكاليف أجور العاملين المرتبة الأولى بين بنود

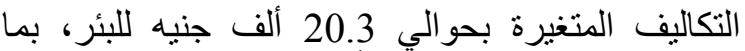
يوازى حوالي 1015.2 جنيهاً للفدان، تمثل نحو 28.8

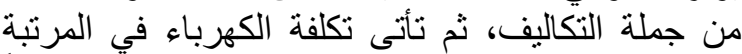

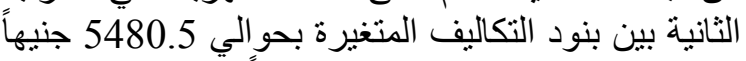

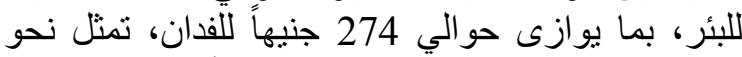

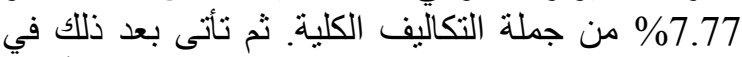

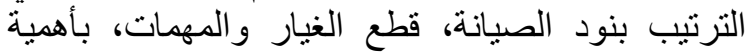
نسبية بلغت نحو 3.29\%، 2.61\% من جملة التكاليف

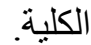

هذا وقد بلغت جملة التكاليف المتغيرة للبئر حوالي

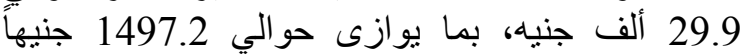
للفدان، تمثل نحو 42.4\% من جملة التكاليف الكلية.

\section{هيكل التكاليف داخل مركز الثيخ زويد}

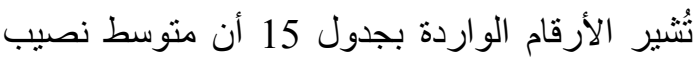

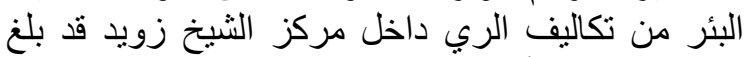

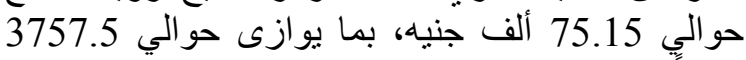
جنيهاً للفدان، ساهمت فيها التكاليف الثابتة بحؤ الي 40.2

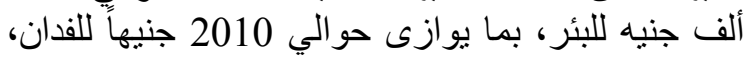
تمثل نحو 53.5\% من جملة التكاليف.
الأهمية النسبية لعدد الآبار السطحية بالقطاع الأهلي حسب ملوحة مياه البئر بعينة البحثث في محافية بلافية شمال سيناء خلال عام 2020

يوضح جدول 12 الأهمية النسبية لعدد الآبار السطحية بالقطاع الأهلي حسب ملوحة مياه البئر بعينة الألة

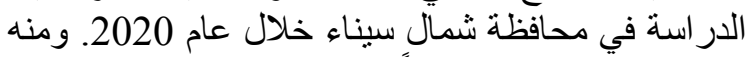

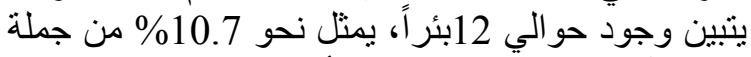

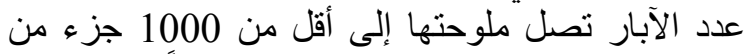

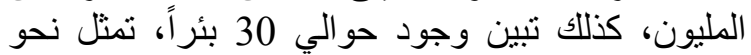

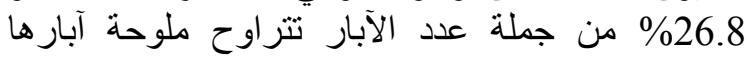
حو الي (1000-2000) جزء في المليون.

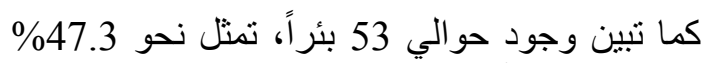

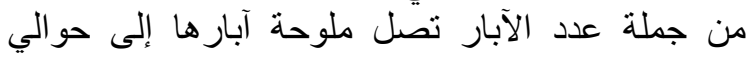

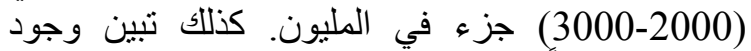

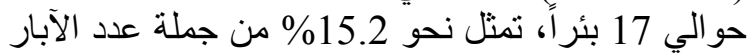
تتر اوح ملوحة آبار ها حو الي 3000 فأكثر جز ع في في المليون.

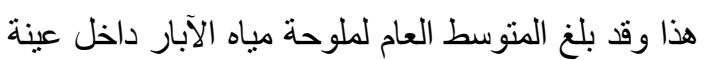

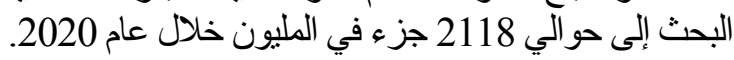
الأهمية النسبية لبنود هيكل تكاليف الري باستخدام الآبار السطية داخل محافظة شمال سيناء خلائل الرل

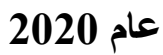

هيكل التكاليف داخل مركز العريش

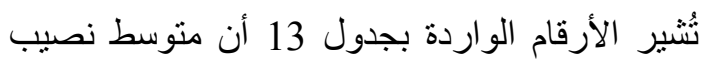

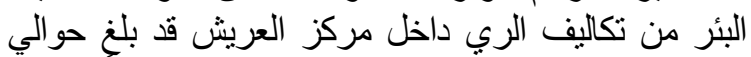
75.42 ألف جنيه، بمأ يوازى حوالي دالي 3771.4 جنيهاً للفدان،

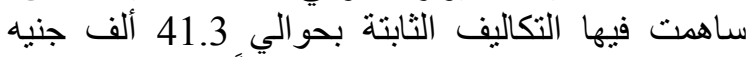

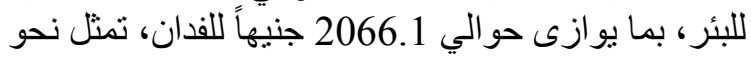
54.8\% من جملة التكاليف.

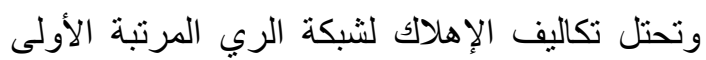

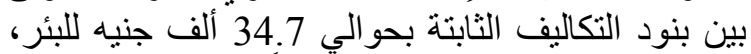

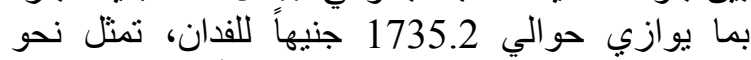

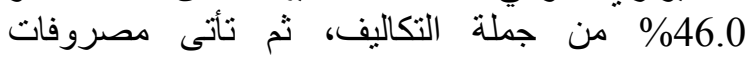
الترخيص في المرتبة الثانية بين بنود التكاليف الثابتة بحوالي 2592.7 جنيهاً للبئر، بمانية يوازى حوالي 129.6

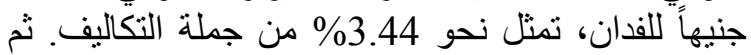

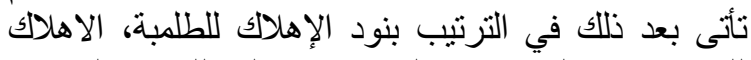

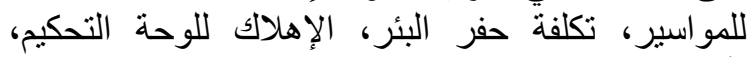

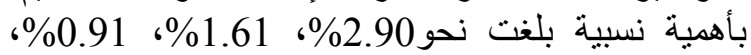
0.37\% من جملة التكاليف الكلية.

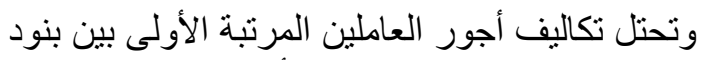

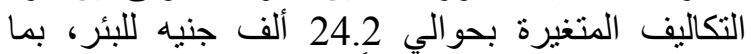

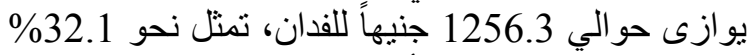
من جملة التكاليف، ثم تأتى تكلفة الكهرباء في المرتبة التبة الثانية بين بنود التكاليف المتغيرة بحوالي 5026 جنيهاً 
جدول 12. الأهمية النسبية لعدد الآبار السطحية بالقطاع الأهلي حسب ملوحة مياه البئر بعينة الدراسة في محافظة

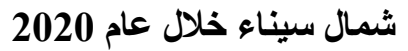

\begin{tabular}{|c|c|c|}
\hline$(\%)$ & عدد الآبار & فئَات الملوحة (جزء في المليون) PPM \\
\hline 10.7 & 12 & $\overline{(1000-0)}$ \\
\hline 26.8 & 30 & $(2000-1000)$ \\
\hline 47.3 & 53 & $(3000-2000)$ \\
\hline 15.2 & 17 & 3000 فأكثر \\
\hline 100 & 112 & عدد الآبار \\
\hline \multicolumn{2}{|c|}{2118 جزء في المليون } & م. ملوحة مياه البئر \\
\hline
\end{tabular}

جدول 13. الأهمية النسبية لبنود هيكل تكاليف الري باستخدام الآبار السطحية داخل مركز العريش بشمال سيناء خلال عام 2020

\begin{tabular}{|c|c|c|c|}
\hline$(\%)$ & م. نصيب الفدان سنويا (جنيه) & م. نصيب البئر (جنيه) & بنود هيكل التكاليف \\
\hline & & & التكاليف الثابتة \\
\hline 3.44 & 129.6 & 2592.7 & مصروفات الترخيص \\
\hline 46.01 & 1735.2 & 34704 & الإهلاك لشبكة الري \\
\hline 0.91 & 34.3 & 686.0 & حفر البئر \\
\hline 1.61 & 43.7 & 874.0 & الإهلاك للمو اسير \\
\hline 2.90 & 109.2 & 2184.0 & الإهلاك للطلمبة \\
\hline 0.37 & 14.1 & 282.0 & الإهلاك للوحة التحكم \\
\hline \multirow[t]{2}{*}{54.78} & 2066.1 & 41322.7 & جملة \\
\hline & & & التكاليف المتغيرة \\
\hline 32.18 & 1256.3 & 24270.0 & أجور العاملين \\
\hline 6.86 & 268.5 & 5026.0 & كهرباء \\
\hline 2.71 & 97.1 & 2042 & قطع غيار ومهمات \\
\hline 3.67 & 125.6 & 2768.0 & صيانة \\
\hline 45.22 & 1747.5 & 34106.0 & جملة \\
\hline 100 & 3771.4 & 75428.7 & الإجمالي العام \\
\hline
\end{tabular}


جدول 14. الأهمية النسبية لبنود هيكل تكاليف الري باستخدام الآبار السطحية داخل مركز بئر العبد بشمال سيناء خلال

عام 2020

\begin{tabular}{|c|c|c|c|}
\hline$(\%)$ & م. نصيب الفدان سنويا (جنيه) & م. نصيب البئر (جنيه) & بنود هيكل التكاليف \\
\hline & & & التكاليف الثابتة \\
\hline 3.61 & 127.2 & 2543.1 & مصروفات الترخيص \\
\hline 47.72 & 1682.3 & 33646.0 & الإهلاك لشبكة الري \\
\hline 1.39 & 48.9 & 977.9 & حفر البئر \\
\hline 1.48 & 52.1 & 1041.4 & الإهلاك للمو اسير \\
\hline 2.97 & 104.8 & 2095.6 & الإهلاك للطلمبة \\
\hline 0.37 & 12.9 & 258.9 & الإهلاك للوحة التحكم \\
\hline \multirow[t]{2}{*}{57.53} & 2038.2 & 40562.9 & جملة \\
\hline & & & التكاليف المتغيرة \\
\hline 28.8 & 1015.2 & 20304.8 & أجور العاملين \\
\hline 7.77 & 274.0 & 5480.5 & كهرباء \\
\hline 2.61 & 92.1 & 1841.5 & قطع غيار ومهمات \\
\hline 3.29 & 115.9 & 2318.8 & 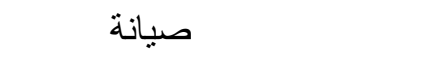 \\
\hline 42.47 & 1497.2 & 29945.6 & جملة \\
\hline 100 & 3535.4 & 70508.5 & الإجمالي العام \\
\hline
\end{tabular}

جدول 15. الأهمية النسبية لبنود هيكل تكاليف الري باستخدام الآبار السطية داخل مركز الثيخ زويد بثمال سيناء خلال عام 2020

\begin{tabular}{|c|c|c|c|}
\hline$(\%)$ & م. نصيب الفدان سنويا (جنيه) & م. نصيب البئر (جنيه) & بنود هيكل التكاليف \\
\hline & & & التكاليف الثابتة \\
\hline 3.15 & 118.2 & 2364.0 & مصروفات الترخيص \\
\hline 45.34 & 1703.5 & 34070.0 & الإهلاك لثبكة الري \\
\hline 0.86 & 32.5 & 650.0 & حفر البئر \\
\hline 1.11 & 41.6 & 832.0 & الإهلاك للمو اسير \\
\hline 2.69 & 101.2 & 2024.0 & الإهلاك للطلمبة \\
\hline 0.35 & 13.0 & 260.0 & الإهلاك للوحة التحكم \\
\hline \multirow[t]{2}{*}{53.49} & 2010 & 40200.0 & جملة \\
\hline & & & التكاليف المتغيرة \\
\hline 33.43 & 1256.3 & 25126.0 & أجور العاملين \\
\hline 7.15 & 268.5 & 5370.0 & كهرباء \\
\hline 2.58 & 97.1 & 1942.0 & قطع غيار ومهمات \\
\hline 3.34 & 125.6 & 2512.0 & صيانة \\
\hline 46.51 & 1747.5 & 34950 & جملة \\
\hline 100 & 3757.5 & 75150.0 & الإجمالي العام \\
\hline
\end{tabular}


مزرعة. وتم الحصول على بيانات الدراسة المُتعلقة

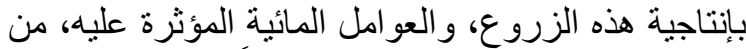

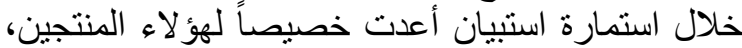

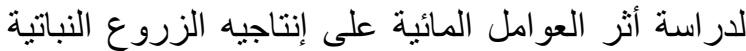
في شمال سيناء خلال موسم إنتاج العابـ 2020.

القياس الإحصائي لأثر العوامل المائية على انتاجية

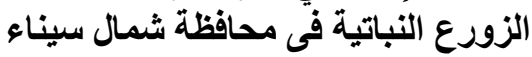

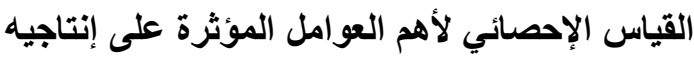
محصول الزيتون تحت نظام الري بالتنقيط داخل الرانل عينة الار اسة الزئون

تشير المعادلة رقم (5) إلى نتائج القياس الإحصائي

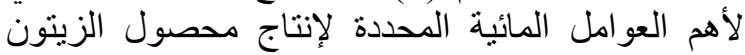
داخل عينة البحث تحت نظام الري بالتنقيط في محافظة الإنة شمال سيناء خلال موسم إنتاج 2020.

Ln qi $=0.34+0.613 \ln x 1+0.481 \ln x 2+$ $0.269 \ln x 3-0.135 \ln x 4$.

$$
\begin{aligned}
& (2.36)^{*}(4.17)^{* *}(3.21)^{* *}(2.39)^{*}(-0.69) \\
& \mathrm{F}=(48.3)^{* *} \mathrm{R}^{12}=0.49 \\
& \text { \% = معنوية عند 5\% **= معنوية عند 10 }
\end{aligned}
$$

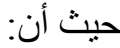

= Ln qi المشاهدة ili

القيمة التقديرية لكمبة مياه الري بالألف م3 سنويا في

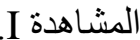

القيمة التقديرية لعدد ساعات الري يوميا بالساعة = X2

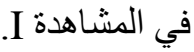
القيمة التقديرية لعدد مرات الري في الموسم في X

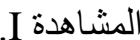

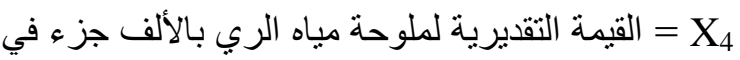

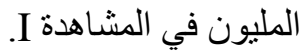

$$
40 \text {...................... } 62 \text { ‘ } 1=\mathrm{i}
$$

المصدر: جمعت وحسبت من بيانات عينة ميدانية بمحافظة

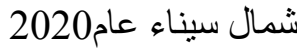

وتثبير التقدير ات المتحصل عليها أن عامل كمية مياه

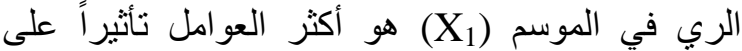

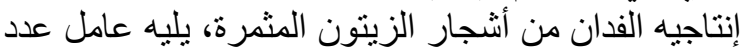

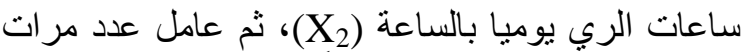

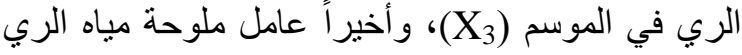

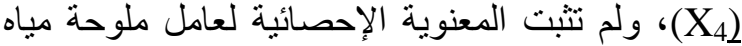

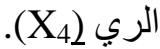

وتحتل تكاليف الإهلاك لنشبكة الري المرتبة الأولى البى

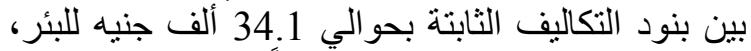
بما يوازى حوالي 1703.5 جنيهاً للفدان، تمثل نحو التئه

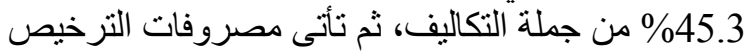

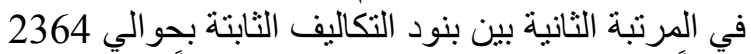
جنيهاً للبئر ، بما يو ازئ بئ حو الي 118.2 جنيهاً للفدان، تمثل

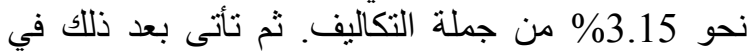

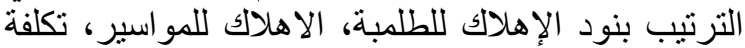

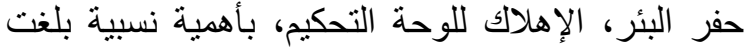

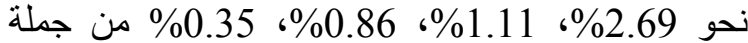

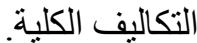

وتحتل تكاليف أجور العاملين المرتبة الأولى بين بنود

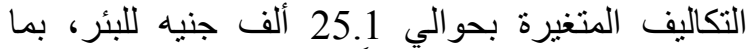

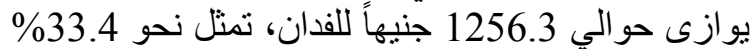
من جملة التكاليف، ثم تأتى تكلفة الكهرباء في المرتبة الثانية بين بنود التكاليف المتغيرة بحوالي 5370 جنئية

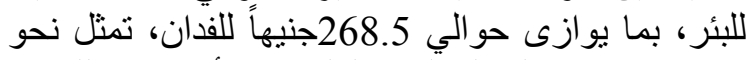

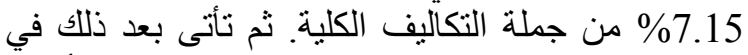
الترتيب بنود الصيانة، قطع الغيار والمهمات، بأهمية نسبية بلغت نحو 3.34\%، 2.58\% من جملة التكاليف

هذا وقد بلغت جملة التكاليف المتغيرة للبئر حوالي جئ

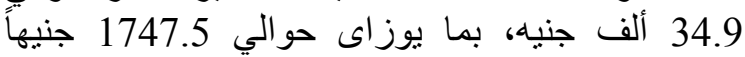
للفدان، تمثل نحو 46.5\% من جملة التكاليف الكلية.

القياس الإحصائي لأثر العوامل المائية على كمية

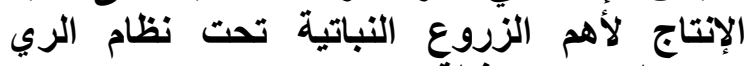
بالتنقيط داخل محافظة شمال سيناء الأباء

يتناول هذا الجزء جانبان، الأول يتناول اختيار عينة

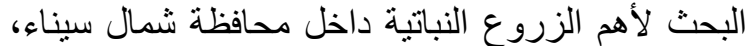

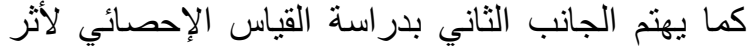

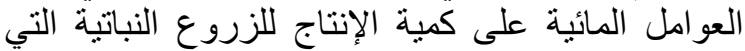

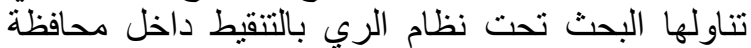
شمال سيناء خلال موسم إنتاج الري 2020.

\section{اختيار عينة الاراسة}

تضمنت الدراسة اختيار محاصيل الزيتون، ممثنا

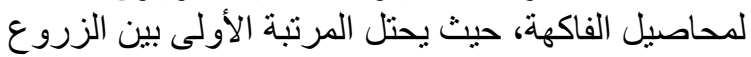

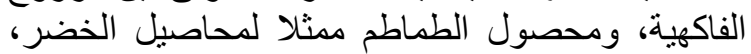

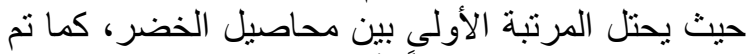
اختيار محصول القمح نظر أ لأهيته على المستوى القومي. وقد تم اختيار عينة عشو ائية طبقية من مز ارعي هذه

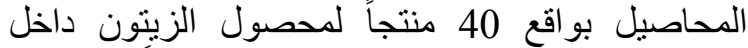

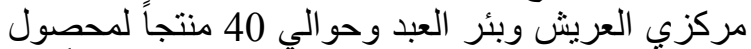
الطماطم، داخل مركزي العريش وبئر العبد، و وأخيراً 15 منتجاً لمحصول القمح داخل مركز بئر العبد العبد وقد بلغ العزي إجمالي العينة لمنتجي الزروع لفي المختارة حوالي 95 
على الترتيب. وتُشير المرونة الإجمالية والبالغة نحو

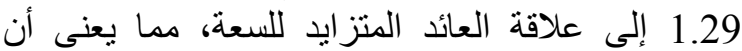

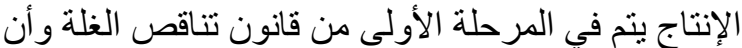

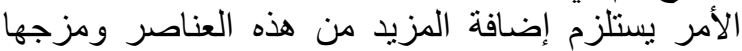
بالطريقة التي تحقق أقصى كفاءة القدئ ممكنة لزيادة الإنتاج، ومن ثم زيادة دخول المنتجين.

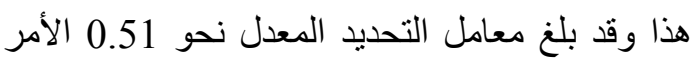

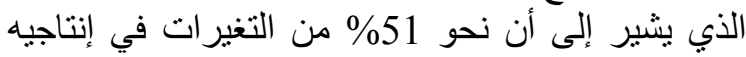

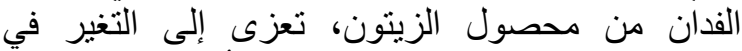

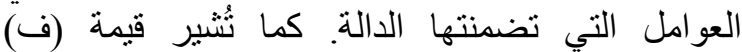
المحسوبة والبالغة نحو 49.9 إلى مدى مطابقة النموذج المئ المستخدم لطبيعية البيانات موضع القياس.

العوامل المائية المحددة لإنتاج محصول الطماطم

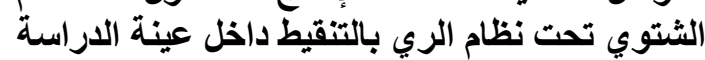

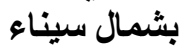

وتثنير المعادلة رقم (7) إلى نتائج القياس الإحصائي

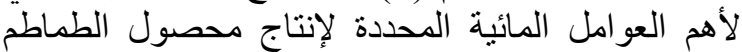

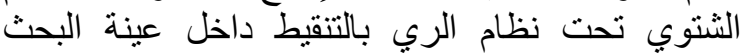
بشمال سيناء خلال موسم إنتاج 2020 باستخدام الإنحدار

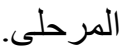

Ln $\mathrm{q}_{\mathrm{i}}=1.64+0.385 \ln \mathrm{x}_{1}+0.142 \ln \mathrm{x}_{2}+0.126 \ln \mathrm{x}_{3}$

$$
(3.71)^{*}(4.66)^{* *} \quad(3.41)^{* *}(2.97)^{*}
$$

$$
\begin{aligned}
& \mathrm{F}=(43.6)^{* *} \mathrm{R}^{12}=0.52 \ldots(7)
\end{aligned}
$$

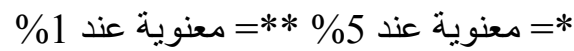

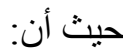

بالس = القيمة التقديرية لإنتاجية فدان الطماطم الثتوي

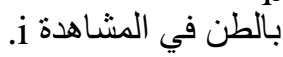
القيمة = القيمة التقديرية لكمية مياه الري بالألف م3 سنويا في

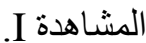

= القيمة التقديرية لعدد ساعات الري يوميا بالساعة

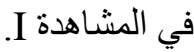
القيمة التقديرية لعدد مرات الري في الموسم في

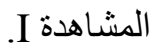
40 ‘2 $11=\mathrm{i}$ المصدر: جمعت وحسبت من بيانات عينة ميدانية بمحافظة شمال سيناء عام2020.

وتُشير التقديرات المتحصل عليها إلى وجود علئاء علاقة

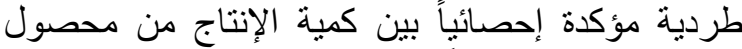

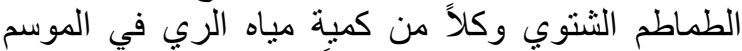

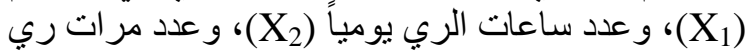

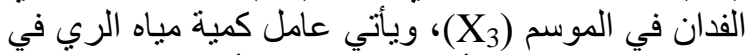

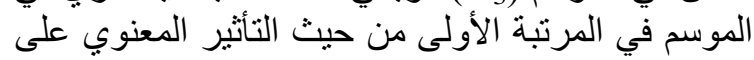

هذا وقد بلغ معامل التحديد المعدل نحو 0.49 الأمر الذي يثير إلى أن نحو 49\% من التغير التيرات في إنتاجيه

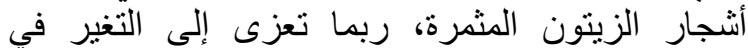
العو امل الثنارحة التي تضمنتها الدالة.

تُشير المعادلة رقم (6) إلى نتائج القياس الإحصائي

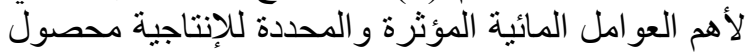

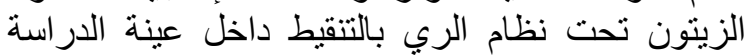
بشمال سيناء خلال موسم إنتاج بات 2020، باستخدام الانحدار

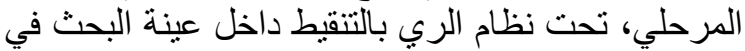
محافظة شمال سيناء خلال موسم إنتاج 2020.

Lnq $_{\mathrm{i}}=0.52+0.649 \ln \mathrm{x}_{1}+0.433 \ln \mathrm{x}_{2}+208 \ln \mathrm{x}_{3}$

$$
(2.61)^{*}(4.83)^{* * *}(3.62)^{* * *}(2.43)^{*}
$$

$\mathrm{F}=(49.9) * * \mathrm{R}^{12}=0.51$

وتشير التقديرات المتحصل عليها إلى وجود علئ علاقة طردية مؤكدة إحصائيا بين كمية الإنتاج من محصول الزئ ودئ

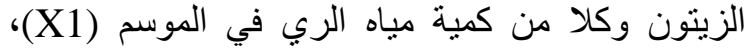

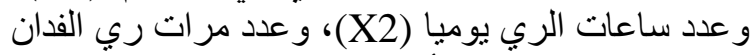

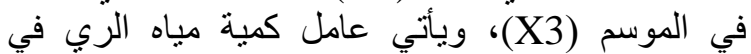

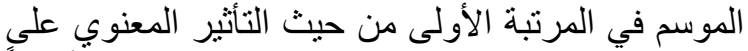

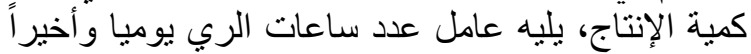
عامل عدد مر ات الري في الموسم.

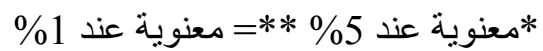
حيث أن: معنو عند

= qi في المشاهدة i. - D. القيمة التقديرية لكمية مياه الري بالألف م3 سنويا في

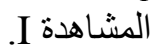
القيمة التقديرية لعدد ساعات الري يوميا بالساعة X2

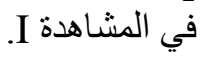
=X3

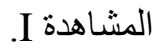
القيمة التقديرية لملوحة مياه الري بالألف جزء في في أل

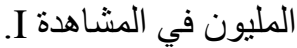
40 $62 \cdot 1=\mathrm{i}$

المصدر: جمعت وحسبت من بيانات عينة ميدانية بمحافظة شمال سيناء عام2020.

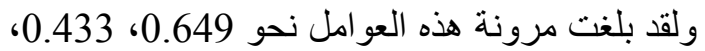

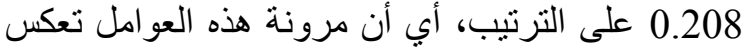

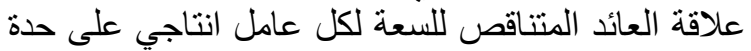

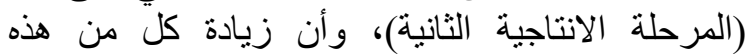

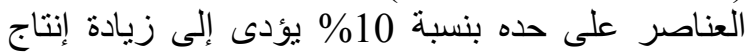

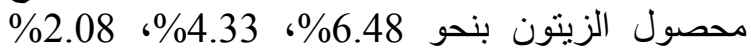


=X2

المشاهدة I.

X $=X_{3}$

Iالمشاهدة I

40

.261 $=\mathrm{i}$

المصدر: جمعت وحسبت من بيانات عينة ميدانية بمحافظة شمال سيناء عام2020.

و أكدت النتائج إلى وجود علاقة طردية بين العوامل

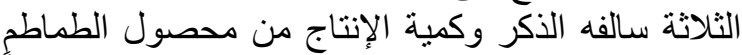
الصيفي، كذللك وجود علاقة عكسية غير مؤكدة إحصائياً

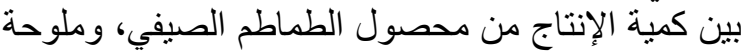

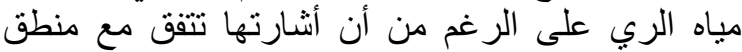

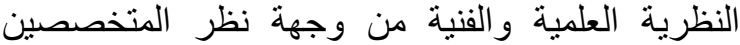
والمشتخلين بالزر اعات الخضرية.

هذا وقد بلغ معامل التحديد المعدل نحو 0.43 الأمر الذي يُشير إلى أن نحو 43\% من التغيرات في إنتاجية

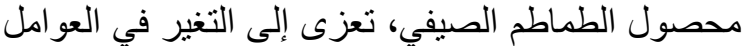

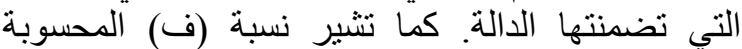
و البالغة نحو 36.8 إلى مدى مطابقة النموذج المستخدم لطبيعية البيانات موضع القياس.

العوامل المائية المحددة لإنتاج محصول الطماطم

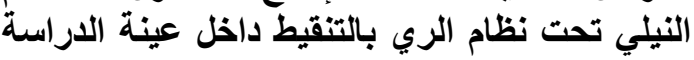
بشمال سبيناء

وتُشير المعادلة رقم (9) إلى نتائج القياس الإحصائي

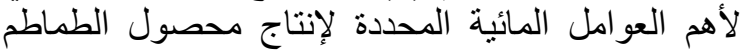

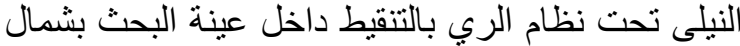
سيناء خلال موسم إنتاج 2020 باستخدام الانحدار

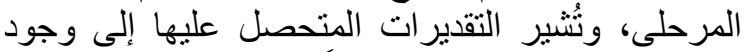
علاقة طردية مؤكدة إحصائياً بين كمية الإنتاج من التهائ

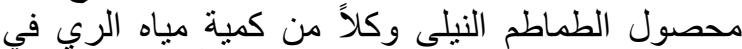

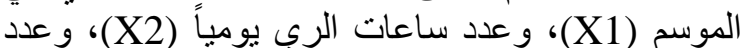

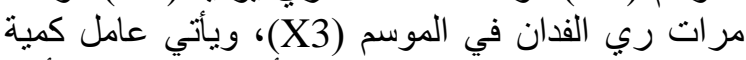

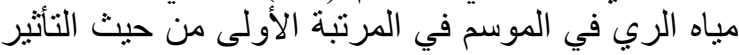
المعنوي على كمية الإنتاج من محصول الطي الطماطم النيلى،

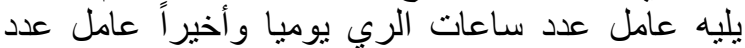

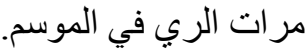

$\ln \mathrm{q}_{\mathrm{i}}=2.69+0.715 \ln \mathrm{x}_{1}+0.382 \ln \mathrm{x}_{2}+0.216 \ln \mathrm{x}_{3}$
$(3.94)^{*}(5.63)$
(3.81)
$(2.74)^{*}$

$\mathrm{F}=(38.5)^{* *} \mathrm{R}^{12}=0.44$

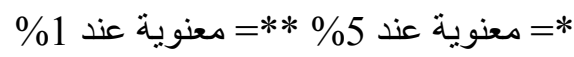

حيث أن:

بnqi بالطن في المشاهدة i
كمية الإنتاج من محصول الطماطم، يليه عامل عدد

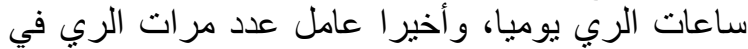
الموسم.

ولقد بلغت مرونة هذه العو امل نحو 0.385، 0.142،

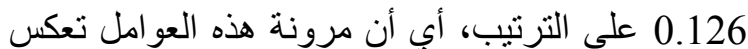

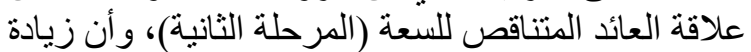
هذه العناصر بنسبة 10\% يؤدى إلى زيادة إنتاج محصول

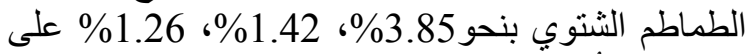

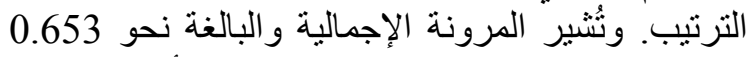
إلى علاقة العائد المتناقص للسعة، مما يعنى أن الإنتاج يتم

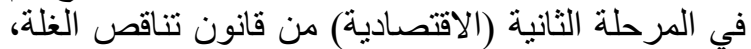

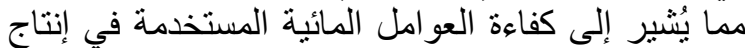
محصول الطماطم الشتوي. هذا وقد بلغ معامل التحديد المعدل نحو 0.52 الأمر الذي يُشير إلى أن نحو 52\% من من التغيرات في إنتاجية

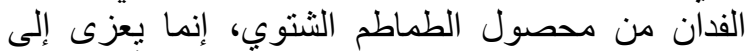

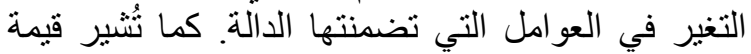
(ف) المحسوبة والبالغة نحو 43.6 إلى الى مدى مطابقة النموذج المستخدم لطبيعية البيانات موضع القياس.

العوامل المائية المحددة لإنتاج محصول الطماطم

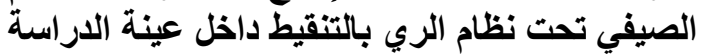
بشمال سيناء

تُشير المعادلة رقم (8) إلى نتائج القياس الإحصائي لأهم

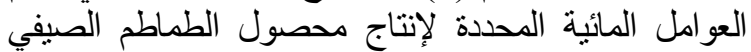
تحت نظام الري بالتتقيط باستخدام الإنحدار المرحلى داخل داخل

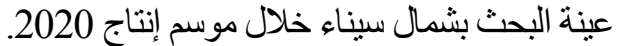
وتُشير التقديرات المتحصل عليها أن عامل كمية مباه

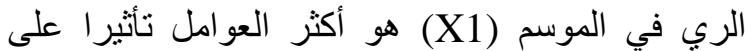

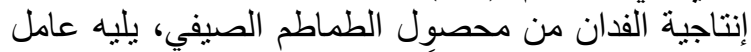

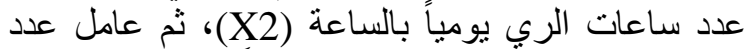

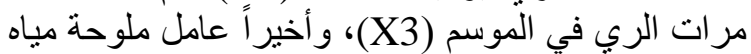

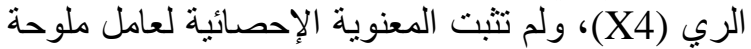
مياه الري (X4). حيث ثبتت المعنوية الإحصائية لهذه

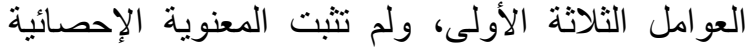
لعامل ملوحة مياه الري (X4) $\ln \mathrm{q}_{\mathrm{i}}=3.18+0.683 \ln \mathrm{x}_{1}+0.369 \ln \mathrm{x}_{2}+0.209 \ln \mathrm{x}_{3}$
$(3.72)^{*}(5.14)^{*}$
$(3.66)^{* *}(2.56)$

$\mathrm{F}=(36.8)^{* *} \mathrm{R}^{12}=0.43$

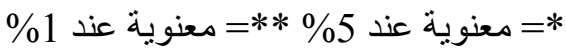

حيث أن:

بnqi بالطن في المشاهدة أiمة. القيمة التقديرية لكمية مباه الري بالألف م3 سنويا في المشاهدة II 
القيمة التقديرية لكمية مياه الري بالألف م3 سنويا في

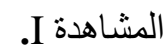

القيمة التقديرية لعدد ساعات الري يوميا بالساعة $=X_{2}$

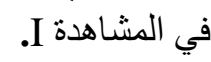

= X

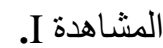

القيمة التقديرية لملوحة مياة الرى بالألف جزئ

$$
\text { فى المليون في المشاهدة I. }
$$

$$
15 \text {.................. } 62 \cdot 1=\mathrm{i}
$$

المصدر: مععت وحسبت من بيانات عينة مبدانية بمحافظة شمال سيناء عام2020.

وتُشير التقدير ات المتحصل علبها أن عامل كمية مياه

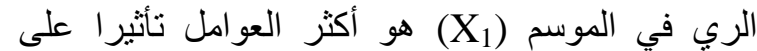

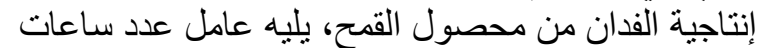

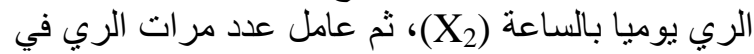

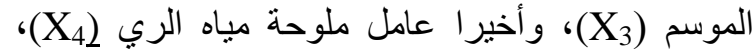
حيث ثبتت المعنوية الإحصائية لهذه العوامل المل جميعا.

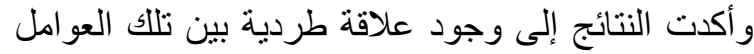
و انتاجية محصول القدح.

هذا وقد بلغ معامل التحديد المعدل نحو 0.48 الأمر الذي يشير إلى أن نحو 48\% من من التغيرات في إنتاجية

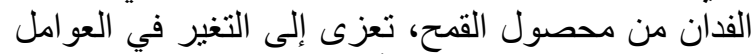

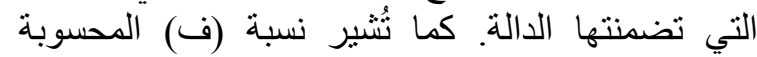
والبالغة نحو 31.6 إلى مدى مطابقة النموذج المستخدم لطبيعية البيانات موضع القياس. نحو مدى وتُشير المعادلة رقم (11) إلى نتائج القياس الإحصائي

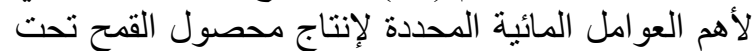

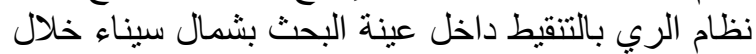

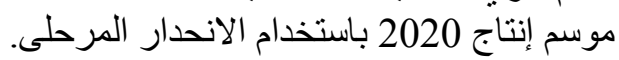
$\ln \mathrm{q}_{\mathrm{i}}=2.66+0.428 \ln \mathrm{x}_{1}+0.226 \ln \mathrm{x}_{2}+0.213 \ln \mathrm{x}_{3}$

$$
(2.63)^{*}(3.91)^{*} \quad(2.85)^{*}(2.747)^{*}
$$

$\mathrm{F}=(35.5)^{* *} \mathrm{R}^{12}=0.49$

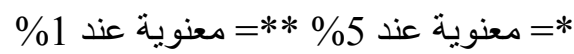

$$
\begin{aligned}
& \text { حيث أن: }
\end{aligned}
$$

فnqi

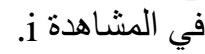
القيمة التقديرية لكمية مياه الري بالألف م3 سنويا في

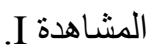

=X

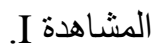

القيمة التقديرية لعدد ساعات الري يوميا بالساعة في =X2

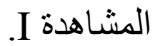

=X3

المشاهدة I.

40 '2،1 $=\mathrm{i}$

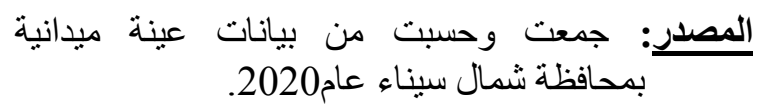

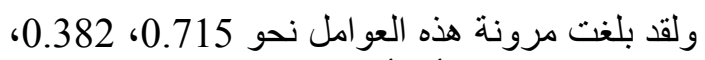

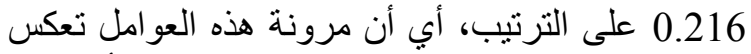

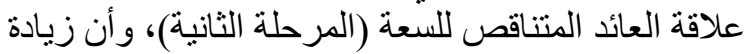
هذه العناصر بنسبة 10\% يؤدى إلى زيادة إنتاج محصول

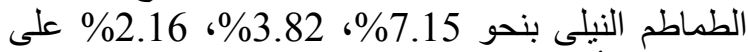
الترتيب. وتُشير المرونة الإجمالية و البالغة نحو 0.313

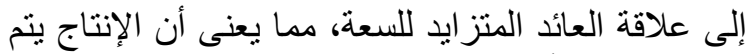

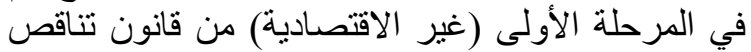

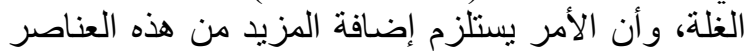

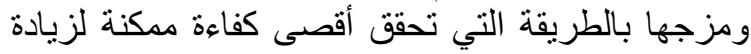
الإنتاج، ومن ثم زيادة دخول المنتجين.

هذا وقد بلغ معامل التحديد المعدل نحو 0.44 الأمر إلى الذي بشير إلى أن نحو 44\% من التغير ات في في إنتاجية

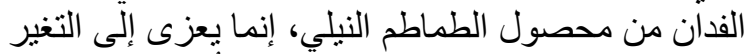

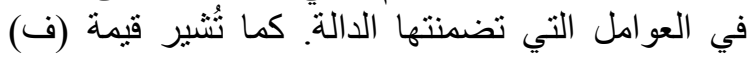
المحسوبة و البالغة نحو 38.5 إلى مدى مطابقة النموذج المستخدم لطبيعية البيانات موضع البع القياس.

\section{العوامل المائية المحددة لإنتاج محصول القمح تحت} نظام الري بالتثقيط داخل عينة الاراسة في الإنة محافظة

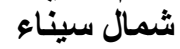

تشير المعادلة رقم (10) إلى نتائج القياس الإحصائي لأهم العوامل المائية المحددة لإنتاج محصول المقاد القمح تحت

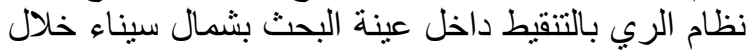

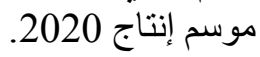
$\ln \mathrm{qi}=1.58+0.417 \ln \mathrm{x} 1+0.214 \ln \mathrm{x} 2+0.195 \ln \mathrm{x} 3-$
$(2.41)^{*}(3.59)^{*}$
$(2.63)^{*}$
$(2.47)^{*}$

\section{$0.113 \ln x 4$}

$$
\mathrm{F}=(31.6)^{* *} \mathrm{R}^{12}=0.48
$$

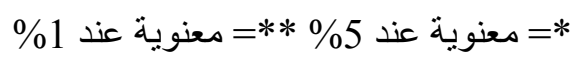
حيث أن: في القيمة التقديرية لإنتاجية فدان القمح بالطن

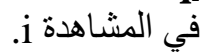


3- ترشيد المزارعين بالمعدلات المنلى لاستخدام مياه

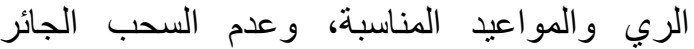
للمحافظة على ملوحة مياه الري.

4- تقدير التكلفة الحقيقية لري الزروع النباتية باستخدام الري بالتنقيط عند تقدير أسعار البيع.

$$
\text { المراجـع }
$$

الامراوي، غادة علي محمد (2013). دراسة اقتصادية

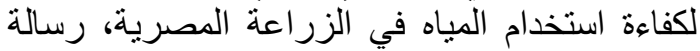

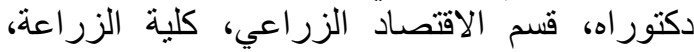

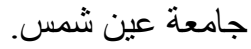

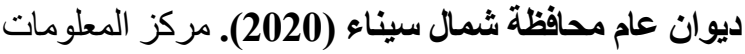
واتخاذ القرار، الكتاب الإحصائي.

رياض، رياض إسماعيل مصطفى، السيد محمد أحمد

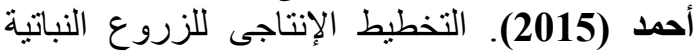
المصرية في ظل الموارد المائية المتاحة، مجلد التراتية

(42)، عدد (2) (2) (2)

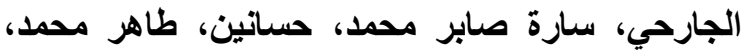
إبراهيم، على احمد، لبن، انور علي مرسي (2020). الموقف الراهن للموارد المائية المتاحة لتحقيق التيق التنمية التية

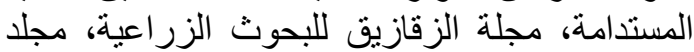
(47)، عدد (3). (3).

السيد، حسين (2011). دراسة تحليلية لاقتصاديات استخدام الموارد المائية في الزراعة المئة المصرية، رسالة الزية دكتور اه، قسم الاقتصاد الزراعي، كلية الزية الزراعة،

$$
\text { جامعة عين شمس. }
$$

عبدالقتاح، محمد عثمان (2013). اقتصاديات الطلب الزبات الحالي والمتوقع على المياه في الزراعة الزمان المصرية،

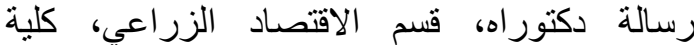
الزر اعة، جامعة عين شمس.

السيد، محمد احمد (2019). البدائل المقترحة للتركيب المحصولي الأمثل في ظل محدودية المدائل الموارد المائية

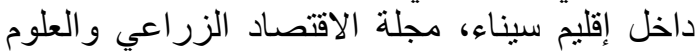
الاجتماعية، مجلد (10)، عدد (10). وزارة الري والموارد المائية (2020). مديرية الرئية الرئية الإدارة العامة للمياه الجوفية، بيانات غير منشورة.

Allen, V.K. and J.L. Sweeney (1985). Economics of water resources, Handbook of Natural Resource and Energy Economics, 2: 465-529.
X القيمة التقديرية لعدد ساعات الري يوميا بالساعة في

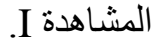
=X القيمة التقديرية لعدد مرات الري في الموسم في

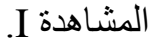
15 $62 \cdot 1=\mathrm{i}$

المصدر: نتائج الحاسب الألى لبيانات البحث الميداني. وتُشير التقديرات المتحصل عليها إلى وجود علئ علاقة

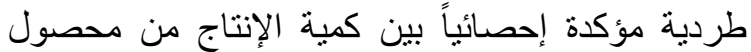

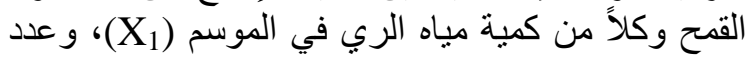

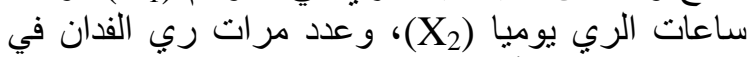

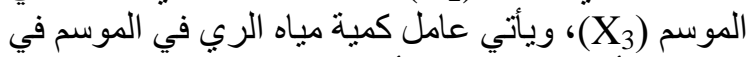
المرتبة الأولى من حيث التأثير المعنوي على على كمية الإنتاج

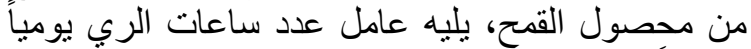
و أخير أ عامل عدد مر ات الري في الموسم.

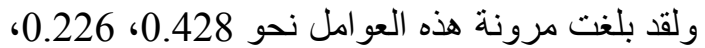
0.213 على الترتيب، أي أن مرونة هذه العئ العو امل تعكس

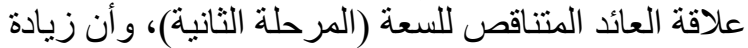
هذه العناصر بنسبة 10\% يؤدى إلى زيادة إنتاج محصول

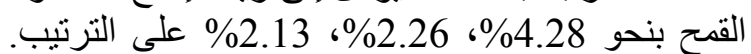
وتُشير المرونة الإجمالية والبالغة نحو 0.867 إلى علاقة التحتي

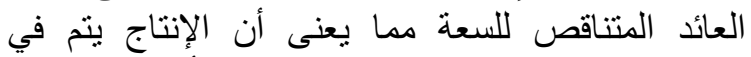
المرحلة الثانية من قانون تناقص الغلة، وأن النان هنالك كفاءة للعو امل المائية المستخدمة في إنتاج القمح.

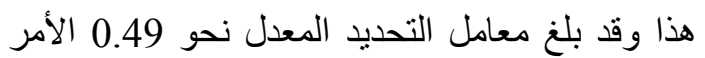

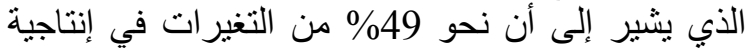

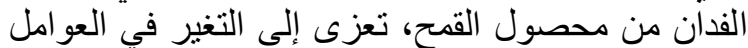

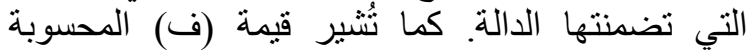

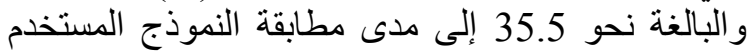
لطبيعية البيانات موضع القياس. التوصيات

فى ضوء النتائج السابقة يوصى البحث بما يلى:

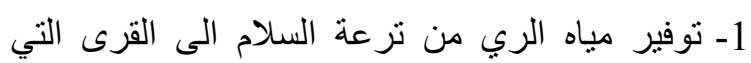
تعاني من ندرة مياه الري داخل ترئ مركز بئر العبد.

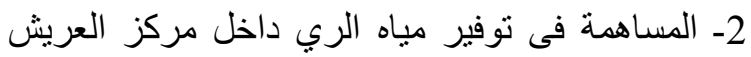
و الثيخ زويد ووسط سيناء من خلال:

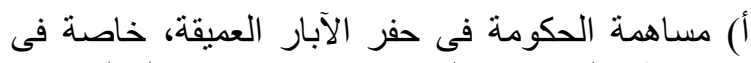
مناطق الزر اعات البستانية، خاصة محصول الزارية الزيتون. ب) مساهمة بنك التنمية والائتمان الزراعي فى تمويل

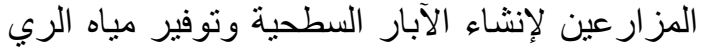

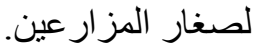




$$
\begin{aligned}
& \text { المُلخص العربي } \\
& \text { دراسة اقتصادية للموارد المائية في محافظة شمال سيناء } \\
& \text { شموع عوض محمد"1، محمد علي أحمد الثـاهد } \\
& \text { 1. قسم الاقتصاد و التنمية الريفية، كلية العلوم الزر اعية البيئية، جامعة العريش، مصر . } \\
& \text { 2. قسم الاقتصاد، كلية الثزوة السمكية، جامعة السويس، مصر. }
\end{aligned}
$$

يهدف البحث بشكل عام إلى در اسة كفاءة استخدام الآبار السطحية في مز ارع شمال سيناء، و أهم العو امل المائية المؤثرة

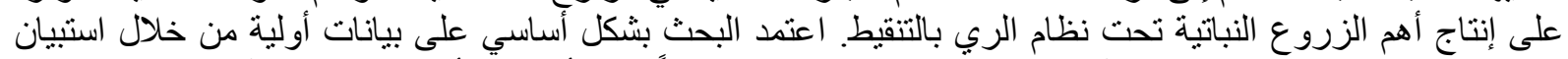
ميداني لعينة عشوائية طبقية من الآبار السطحية تتكون من 112 بئراً على أساس الأهمية النسبية للآبار السطحية، وتم

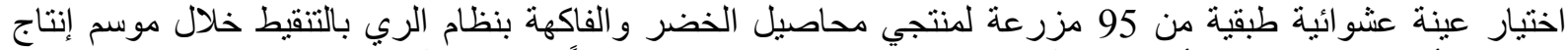

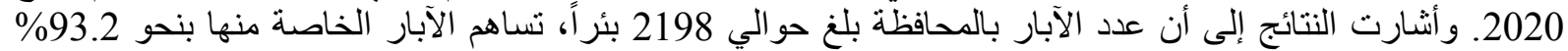

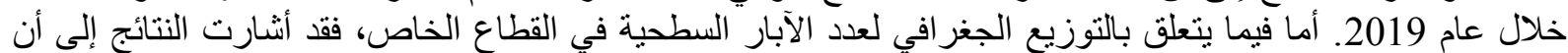

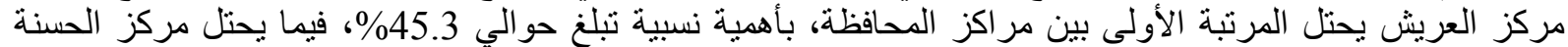

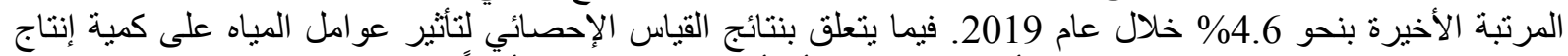

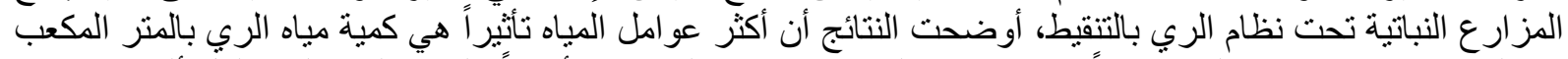

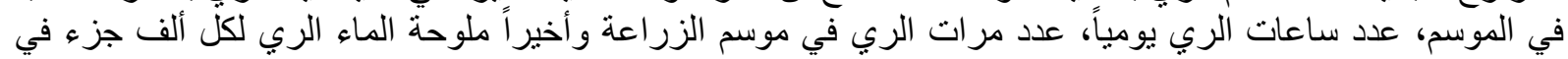
المليون.

الكلمات الإسترشادية: الموارد المائية، الآبار السطحية، القياس الإحصائي، المرونة الإجمالية. 
